\title{
Health Effects Associated with Energy Conservation Measures in Commercial Buildings
}

Volume 1: Summary

R. D. Stenner

M. C. Baechler

September 1990

Prepared for

the Bonneville Power Administration under a Related Services Agreement with the U.S. Department of Energy

Contract DE-AC06-76RLO 1830

Pacific Northwest Laboratory

Operated for the U.S. Department of Energy

by Battelle Memorial Institute 


\title{
DISCLAIMER
}

This report was prepared as an account of work sponsored by an agency of the United States Government. Neither the United States Government nor any agency thereof, nor Battelle Memoriai Institute, nor any of their einployees, makes any warranty, expressed or implied, or assumes any legal liability or responsibility for the accuracy, completeness, or usefuliness of any information, apparatus, product, or process disclosed, or represents that its use would not infringe privately owned rights. Reference herein to any specific commercial product, process, or service by trade name, trademark, manufacturer, or otherwise, does not necessarily constitute or imply its endorsement, recommendation, of favoring by the United States Government or any agency thereof, or Battelle Memorial Institute. The views and opinions of authors expressed herein do not necessarily state or rellect those of the United States Government or any agency thereof.

\author{
PACIFIC NORTHWEST LABORATORY \\ operated by \\ BATTELLE MEMORIAL INSTITUTE \\ for the \\ UNITED STATES DEPARTMENT OF ENERGY \\ under Contract DE-AC06-76RLO 1830
}

Printed in the United States of America

Availahle to DOE and DOE contractors from the

Officc of Scientific and Technical Information, P.O. Box 62, Oak Ridge, TN 37831; prices available from (615) 576-8401. FT5 626-8401.

Available to the public from the National Technical Information Service. U.S. Depariment of Commerce, 5285 Port Royal Rd., Springfield. VA 22161.

NTIS Price Codes, Microfictie AOI

Printed Copy

\begin{tabular}{cr}
\hline Price Code & Page Range \\
\hline A02 & $1-10$ \\
A03 & $11-50$ \\
A04 & $51-75$ \\
A05 & $76-100$ \\
A06 & $101-125$ \\
A07 & $126-150$ \\
A08 & $151-175$ \\
A09 & $176-200$ \\
A10 & $201-225$ \\
A11 & $226-250$ \\
A12 & $251-275$ \\
A13 & $276-300$ \\
A14 & $301-325$
\end{tabular}

\begin{tabular}{cc}
\hline Price Code & Page Range \\
\hline A15 & $326-350$ \\
A16 & $351-375$ \\
A17 & $376-400$ \\
A18 & $401-425$ \\
A19 & $426-450$ \\
A20 & $451-475$ \\
A21 & $476-500$ \\
A22 & $501-525$ \\
A23 & $526-550$ \\
A24 & $551-575$ \\
A25 & $576-600$ \\
A99 & $601-U p$
\end{tabular}


HEALTH EFFECTS ASSOCIATED

WITH ENERGY CONSERVATION MEASURES

IN COMMERCIAL BUILDINGS

VOLUME 1: SUMMARY

R. D. Stenner

M. C. Baechler

September 1990

Prepared for the Bonneville Power Administration under a Related Services Agreement with the U.S. Department of Energy Contract DE-AC06-76RLO 1830

Pacific Northwest Laboratory

Richland, Washington 99352 



\section{SUMMARY}

Indoor air quality can conceivably be impacted by hundreds of different chemicals. More than 900 different organic compounds alone have been identified in indoor air. The health effects that could potentially arise from exposure to individual pollutants or mixtures of pollutants cover the full range of acute and chronic effects, including largely reversible responses, such as rashes and irritations, as well as irreversible toxic and carcinogenic effects. These indoor contaminants are emitted from a large variety of materials and substances that are widespread components of everyday life.

Pacific Northwest Laboratory conducted a search of the peer-reviewed literature on health effects associated with indoor air contaminants for the Bonneville Power Administration to aid the agency in the preparation of environmental documents. The results of this search are reported in two volumes. Volume 1 is a summary of the results of the literature search; Volume 2 is the complete results of the literature search and contains all references to the material reviewed.

The health effects information available for each contaminant varies widely. A vast amount of health-effects-related information is available on some of the contaminants, such as polychlorinated biphenyls and formaldehyde. However, very little or no information is available on others, such as $\alpha$ pinene and octene. Although for some contaminants the information provided in this report may be limited, it reflects what is available at this time. This information is summarized in Table S.I, which lists descriptive chemical data, hazard ratings, exposure limits, and carcinogenicity ratings. 


\section{TABLE S.l. Summary of Quantitative Data on Contaminants}

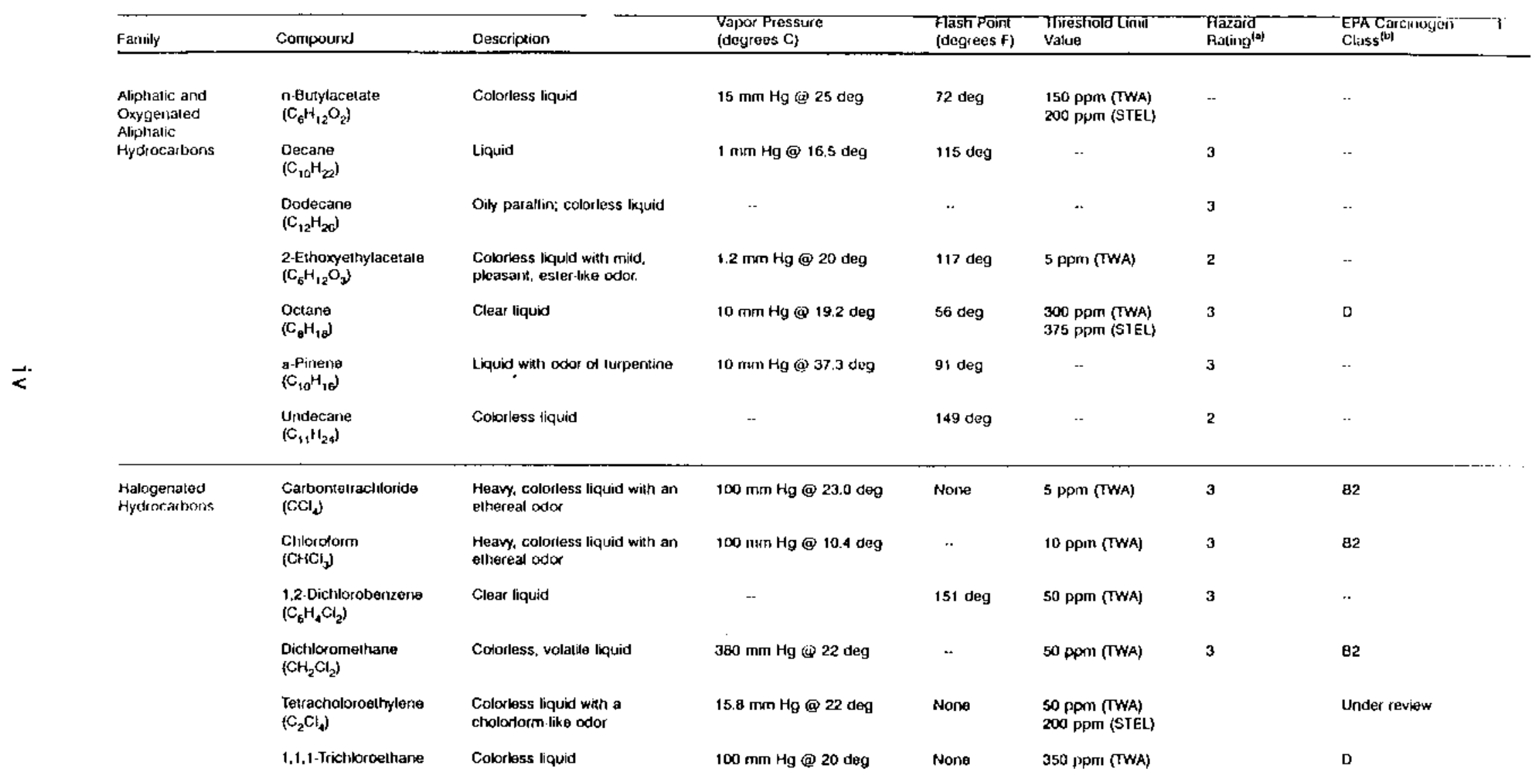


TABLE S.1. (contd)

\begin{tabular}{|c|c|c|c|c|c|c|c|}
\hline Fantily & Compound & Descriptions & $\begin{array}{l}\text { Vapor Prossute } \\
\text { (degrees C) }\end{array}$ & $\begin{array}{l}\text { Flash Poink } \\
\text { (degrees } \mathrm{F} \text { ) }\end{array}$ & $\begin{array}{l}\text { Thireshodd Lirmil } \\
\text { Value }\end{array}$ & $\begin{array}{l}\text { Pazard } \\
\text { Rating }\end{array}$ & $\begin{array}{l}\text { EPA Cácininogen } \\
\text { Class }\end{array}$ \\
\hline & $\left(\mathrm{C}_{2} \mathrm{H}_{3} \mathrm{Cl}_{3}\right)$ & & & & 450 pOM (S TEL) & & \\
\hline & $\begin{array}{l}\text { 1,1,1-Trichiloroethylerie } \\
\left(\mathrm{C}_{2} \mathrm{HCl}_{3}\right)\end{array}$ & $\begin{array}{l}\text { Mobila liquid with a } \\
\text { characterisic odor ol } \\
\text { chlofolorm }\end{array}$ & $100 \mathrm{~mm} \mathrm{Hg} 932 \mathrm{deg}$ & 89.6 deg & $\begin{array}{l}50 \mathrm{ppm} \text { (TWA) } \\
200 \text { PXII (STEL) }\end{array}$ & & 82 \\
\hline \multirow[t]{7}{*}{$\begin{array}{l}\text { Atorlanc } \\
\text { Hydrocarbons }\end{array}$} & $\begin{array}{l}\text { Benzene } \\
\left\{\mathrm{C}_{6} \mathrm{H}_{2}\right\rangle\end{array}$ & Clear, cotorinss liquid & $100 \mathrm{~mm} H \mathrm{Hg} \Leftrightarrow 20.1 \mathrm{deg}$ & 12 deg & $10 \mathrm{pP} \cap$ (TWA & 3 & A \\
\hline & $\begin{array}{l}\text { Ellyyluenzene } \\
\left(\mathrm{C}_{\mathrm{a}} \mathrm{H}_{10}\right)\end{array}$ & $\begin{array}{l}\text { Colorless liquid will in) } \\
\text { arorzatic odor }\end{array}$ & $100 \mathrm{mun} \mathrm{Hg}$ (1) $26.9 \mathrm{deg}$ & $50 \mathrm{deg}$ & $\begin{array}{l}100 \text { pion (TWA) } \\
125 \text { p)rol (SIEL) }\end{array}$ & 2 & D \\
\hline & $\begin{array}{l}\text { Propylbenzene } \\
\left(\mathrm{C}_{9} \mathrm{H}_{12}\right)\end{array}$ & $\begin{array}{l}\text { Clear liquid, insoluablo in } \\
\text { waler, miscible in alcotiod and } \\
\text { ether }\end{array}$ & $10 \mathrm{amm} 4 \mathrm{sg} Q 43.4 \mathrm{deg}$ & BG deg & -. & $\mathbf{3}$ & .. \\
\hline & $\begin{array}{l}\text { Styrene } \\
\left(\mathrm{C}_{8} \mathrm{H}_{0}\right)\end{array}$ & Colorkess, refraclive, oily liquid & -- & es deg & $\begin{array}{l}50 \mathrm{ppm} \text { (TWA) } \\
100 \mathrm{ppm} \text { (STEL) }\end{array}$ & 3 & Under teveiv \\
\hline & $\begin{array}{l}\text { Toluene } \\
\left(C_{7} H_{\theta}\right)\end{array}$ & $\begin{array}{l}\text { Colvelkess liquid with a berizol- } \\
\text { like odor }\end{array}$ & $36.7 \mathrm{mrn} \mathrm{Hg} @ 30 \mathrm{deg}$ & $40 \mathrm{deg}$ & $\begin{array}{l}100 \mathrm{ppm} \text { (TWA) } \\
150 \mathrm{pipm} \text { (STEL) }\end{array}$ & 3 & $\mathbf{D}$ \\
\hline & $\begin{array}{l}1,2,4-T_{\text {rimethy benzene }} \\
\left(\mathrm{C}_{9} \mathrm{H}_{12}\right)\end{array}$ & Liquid & -. & $130 \mathrm{deg}$ & 25 рРाн (TWA) & 2 & 0 \\
\hline & $\begin{array}{l}\text { Xylene } \\
\left(\mathrm{C}_{8} \mathrm{H}_{10}\right)\end{array}$ & Clear liquid & $6.72 \mathrm{~mm}$ hg @ 21 deg & 100 deg & $\begin{array}{l}100 \text { ppm (WWA) } \\
150 \mathrm{ppm} \text { (TWA) }\end{array}$ & 3 & D \\
\hline Keiones & $\begin{array}{l}\text { Melliylettylketone } \\
\left\{\mathrm{C}_{4} \mathrm{H}_{\mathrm{B}} \mathrm{O}\right)\end{array}$ & $\begin{array}{l}\text { Colorless liquid with an } \\
\text { acetone.like odor }\end{array}$ & $71.2 \mathrm{~mm} \mathrm{Hg} @ 20 \mathrm{deg}$ & $22 \mathrm{deg}$ & $\begin{array}{l}200 \text { ppin (TWA) } \\
300 \text { ppin (STEL) }\end{array}$ & 3 & 0 \\
\hline Aldehydes & $\begin{array}{l}\text { Formakdehyde } \\
\left(\mathrm{CH}_{2} \mathrm{O}\right)\end{array}$ & $\begin{array}{l}\text { Clear, water-white, very slightly } \\
\text { acid gas or liquid will? a pun- } \\
\text { genll odor }\end{array}$ & $10 \mathrm{~mm} \mathrm{Hg} @ \cdot \theta 8 \mathrm{deg}$ & $122 \mathrm{deg}$ & $\begin{array}{l}1 \text { pom (TWA) } \\
2 \text { POM (STEL) }\end{array}$ & 3 & B1 \\
\hline
\end{tabular}




\section{IABLE S.1. (contd)}

\begin{tabular}{|c|c|c|c|c|c|c|c|}
\hline Fallsily & Compound & Descriplion & $\begin{array}{l}\text { Vapor Pressure } \\
\text { (degjees } \mathrm{C} \text { ) }\end{array}$ & $\begin{array}{l}\text { मlash Foiñ } \\
\text { (degrees } F \text { ) }\end{array}$ & $\begin{array}{l}\text { Thieshold cimit } \\
\text { Vulua }\end{array}$ & $\begin{array}{l}\text { Hivard } \\
\text { Ralingit) }\end{array}$ & $\begin{array}{l}\text { EPA Carcino(jen } \\
\text { Clisss }\end{array}$ \\
\hline & $\begin{array}{l}\text { Radon/Radon Progeny } \\
(\text { Nil) }\end{array}$ & $\begin{array}{l}\text { Colorless, odlorless, very dense } \\
\text { inert gas }\end{array}$ & .. & $91 \mathrm{deg}$ & .. & 3 & Under revicw \\
\hline \multirow[t]{3}{*}{ Caulk Cormpousts } & $\begin{array}{l}\text { Carbitol } \\
\left\langle\mathrm{C}_{6} \mathrm{H}_{14} \mathrm{O}_{3}\right)\end{array}$ & $\begin{array}{l}\text { Colorless liquid with amits } \\
\text { pleasani odor }\end{array}$ & - & $201 \mathrm{deg}$ & .. & 2 & .. \\
\hline & $\begin{array}{l}\text { Ethytena Glycol } \\
\left(\mathrm{C}_{2} \mathrm{H}_{6} \mathrm{O}_{2}\right)\end{array}$ & $\begin{array}{l}\text { Colorless, sweel-tasting, hygro- } \\
\text { scopic liquid. }\end{array}$ & $0.05 \mathrm{~mm}$ Hg@ $20 \mathrm{deg}$ & $232 \mathrm{deg}$ & $50 \mathrm{ppm}$ (TWA) & 3 & -. \\
\hline & Ociene & Colorless tiquid & .. & .. & .. & .. & .. \\
\hline \multirow[t]{4}{*}{$\begin{array}{l}\text { Combustion } \\
\text { Products }\end{array}$} & $\begin{array}{l}\text { Benzo(A) Pyrene } \\
\left(\mathrm{C}_{20} \mathrm{H}_{12}\right)\end{array}$ & $\begin{array}{l}\text { Yellow crystals, insoluable in } \\
\text { waler, soluables in benzene, to- } \\
\text { luene, and } x y \text { teriti }\end{array}$ & .- & .. & -. & 3 & 82 \\
\hline & $\begin{array}{l}\text { Carbon Mansoxido } \\
(\mathrm{CO})\end{array}$ & Colorless, odurless gas & .. & .. & .. & 3 & .. \\
\hline & $\begin{array}{l}\text { Carbon Droxide } \\
\left(\mathrm{CO}_{2}\right)\end{array}$ & Colorless, odorless gas & - & .. & $\begin{array}{l}5.000 \mathrm{ppm} \text { (TWA) } \\
30,000 \mathrm{ppm} \text { (STEL) }\end{array}$ & 1 & .. \\
\hline & $\begin{array}{l}\text { Ervironnerital Tobacto } \\
\text { Smoke }\end{array}$ & .. & -- & -. & .. & D & Unider reveiw \\
\hline Fibers & Astbestos & & .. & .. & -- & 3 & $A$ \\
\hline PCES & PCBs & $\begin{array}{l}\text { Range in cot sistency Irom } \\
\text { heavy olly liquinds io waxy } \\
\text { solids }\end{array}$ & $7.75 \mathrm{E}-5 \mathrm{~mm} \mathrm{Hg}$ & $200 \mathrm{deg} C$ & $\begin{array}{l}0.001 \mathrm{mg} / \mathrm{m}^{3} \text { lor } \\
10-\mathrm{hr} \mathrm{day}, 40 \mathrm{hr} \\
\text { week (NIOSH) }\end{array}$ & 3 & B2 \\
\hline
\end{tabular}


TABLE S.1. (contd)

\begin{tabular}{|c|c|c|c|c|c|c|c|}
\hline Family & Compound & Descriplion & $\begin{array}{l}\text { Vapor Pressure } \\
\text { (degroess C) }\end{array}$ & $\begin{array}{l}\text { Flastipoind } \\
\text { (degrees F) }\end{array}$ & $\begin{array}{l}\text { Thireshord Limin } \\
\text { Value }\end{array}$ & $\begin{array}{l}\text { Parard } \\
\text { Pating }{ }^{(\mathrm{s})}\end{array}$ & $\begin{array}{l}\text { EPA Carrcinogenti } \\
\text { Class }{ }^{(b)}\end{array}$ \\
\hline & & & & & $\begin{array}{l}0.5 \text { to } 1.0 \mathrm{mg} / \mathrm{m}^{3} \\
\text { lor B.hr day } \\
\text { (OSi iA) }\end{array}$ & & \\
\hline \multirow[t]{3}{*}{ CFCs } & Freonl 113 & .. & .. & -- & .. & 1 & -- \\
\hline & Freon 11 & .. & .. & -- &. & 3 &.. \\
\hline & Freon F-12 & .- & .. & .. & & 1 & .. \\
\hline
\end{tabular}

(a) Sax and Lewis Hazard Aating

ib) EPA Weight $\alpha$ Evidence Classitication lor Carcinogenicity 


\section{$\checkmark$}




\section{CONTENTS}

SUMMARY

1.0 INTRODUCTION . . . . . . . . . . . . . . . . 1.1

1.1 INDOOR AIR CONTAMINANTS . . . . . . . . . . . . 1.1

1.2 LIMITATIONS TO THE DATA . . . . . . . . . . . 1.3

2.0 INTERPRETING THE HEALTH EFFECTS INFORMATION . . . . . . . . . 2.1

2.1 CHEMICAL DATA ................... 2.1

2.2 TOXIC EFFECTS . . . . . . . . . . . . . . . 2.1

2.3 CARCINOGENICITY . . . . . . . . . . . . . 2.3

2.4 REPRODUCTIVE AND DEVELOPMENTAL EFFECTS . . . . . . . 2.4

3.0 VOLATILE ORGANIC COMPOUNDS . . . . . . . . . . . . . . . 3.1

3.1 ALIPHATIC AND OXYGENATED ALIPHATIC HYDROCARBONS $\quad . \quad \ldots .2$

3.1.1 n-Butyl Acetate ................ 3.2

3.1 .2 Decane ................. 3.4

3.1.3 Dodecane . . . . . . . . . . . . . . 3.4

3.1.4 2-Ethoxy Ethyl Acetate ............. 3.4

3.1.5 octane ................. 3.5

3.1 .6 a-Pinene ................. 3.5

3.1 .7 Undecane . . . . . . . . . . . . . . 3.6

3.2 HALOGENATED HYDROCARBONS . . . . . . . . . . . . . 3.6

3.2.1 Carbon Tetrachloride . . . . . . . . . . . . . . 3.6

3.2.2 Chloroform . . . . . . . . . . . . . . 3.8

3.2.3 1,2-Dichlorobenzene ................ . . . . . . .

3.2.4 Dichloromethane . . . . . . . . . . 3.10

3.2.5 Tetrachloroethylene ............. . 3.10 
3.2.6 1, l, 1-Trichloroethane ........... 3.12

3.2.7 1,1,1-Trichloroethylene .......... 3.13

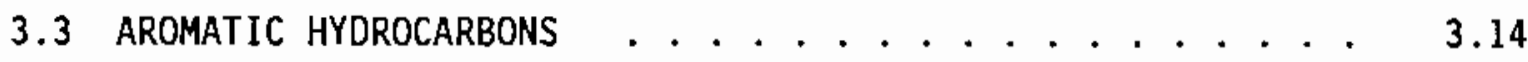

3.3.1 Benzene ..................... 3.14

3.3.2 Ethyl Benzene . . . . . . . . . . 3.15

3.3.3 Propyl Benzene . . . . . . . . . . . 3.16

3.3 .4 Styrene ................. 3.16

3.3.5 Toluene .................. . . . 3.17

$3.3 .6 \quad 1,2,4$-Trimethylbenzene $\ldots \ldots \ldots . \ldots 3.18$

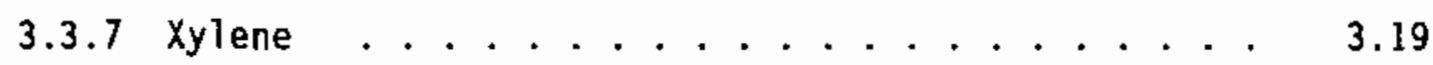

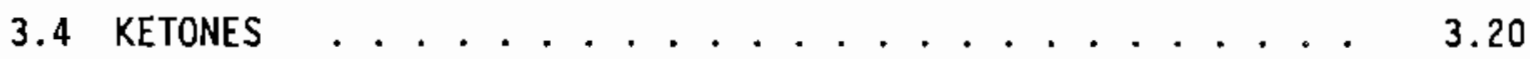

3.4.1 Methyl Ethyl Ketone ............ 3.20

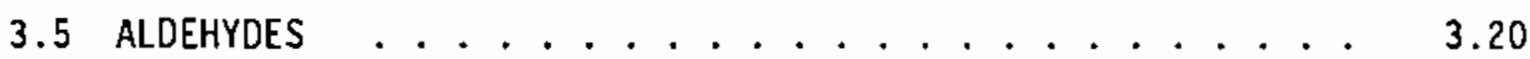

3.5.1 Formaldehyde .............. 3.20

4.0 RADON/RADON PROGENY .......................... 4.1

5.0 ADDITIONAL CAULK-ASSOCIATED COMPOUNDS .......... 5.1

5.1 CARBITOL ............................ 5.1

5.2 ETHYLENE GLYCOL . . . . . . . . . . . . 5.1

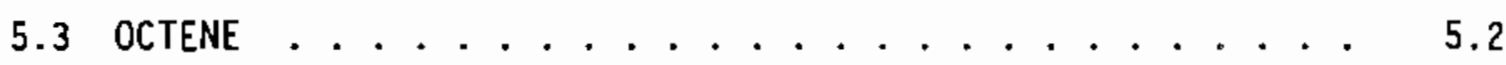

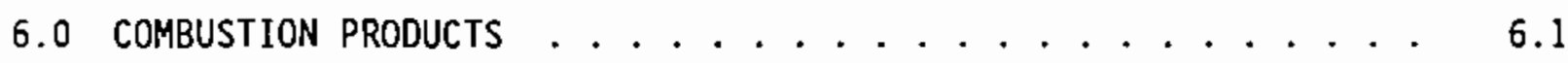

6.1 BENZO[a]PYRENE ..................... 6.2

6.2 CARBON MONOXIDE ....................... 6.3

6.3 CARBON DIOXIDE . . . . . . . . . . . . . . 6.4

6.4 ENVIRONMENTAL TOBACCO SMOKE ................ 6.4

6.5 NITROGEN OXIDES ............................ 6.5 
7.0 FIBERS $\ldots \ldots \ldots \ldots \ldots . \ldots \ldots . \ldots \ldots$

7.1 ASBESTOS .............................. 7.1

7.2 SYNTHETIC FIBERS . . . . . . . . . . . . 7.3

8.0 BIOGENIC PARTICLES . . . . . . . . . . . . 8.1

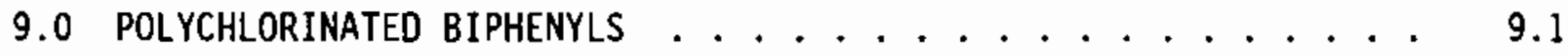

10.0 CHLOROFLUOROCARBONS . . . . . . . . . . . 10.1

10.1 DIRECT EFFECT OF CFCs . . . . . . . . . . . 10.1

10.1.1 1,1,2-Trich1oro-1,2,2-Trifluoroethane ..... 10.1

10.1.2 Trichlorofluoromethane ......... 10.2

10.1.3 Dichlorodifluoromethane . . . . . . . 10.2

10.2 STRATOSPHERIC OZONE LAYER REDUCTION HEALTH EFFECTS . . 10.3

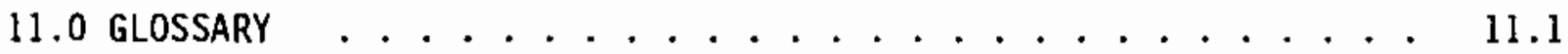


TABLES

S.1 Summary of Quantitative Data on Contaminants . . . . . . . iv

1.1 Contaminants Examined in Health Effects Study . . . . . . . 1.3

2.1 Sax and Lewis' Chemical Hazard Rating Scale . . . . . . . . . 2.2

2.4 EPA Carcinogenic Weight-of-Evidence Classifications . . . . . . 2.4

3.1 Examples of Organic Compounds and Sources . . . . . . . . . . 3.3

7.1 Types of Fibers Potentially Encountered in Commercial
Buildings . . . . . . . . . . . . . . . . . . . . . 7.2 


\subsection{INTRODUCTION}

The purpose of this document is to summarize the peer-reviewed literature on health effects associated with indoor air contaminants. This report is presented in two volumes. This volume (Volume 1) is a summary document; Volume 2 is the complete results of the literature search and contains all references to the literature reviewed. Pacific Northwest Laboratory (PNL) (a) prepared this review for the Bonneville Power Administration (Bonneville) to aid the agency in the preparation of environmental documents. Bonneville has taken a leading role among federal agencies in assessing the environmenta] impacts of its conservation acquisition programs. These efforts have included extensive research programs into residential ventilation and indoor pollution characterization and monitoring. Bonneville has also prepared three environmental documents under the National Environmental Policy Act (NEPA) that focused on indoor air quality issues.

One of these documents, the 1982 Environmental Assessment of Energy Conservation Opportunities in the Commercial-Sector Facilities in the Pacific Northwest, supported conservation programs in existing buildings. Bonneville is now planning the implementation of aggressive commercial conservation programs in both new and existing buildings. Because of changing information, and because of the change in scope of the anticipated programs, Bonneville is now revisiting the potential environmental effects of conservation activities in commercial buildings.

\subsection{INDOOR AIR CONTAMINANTS}

Indoor air quality can conceivably be impacted by hundreds of different chemicals. More than 900 different organic compounds alone have been identified in indoor air. The health effects that could potentially arise from exposure to individual pollutants or mixtures of pollutants cover the full range of acute and chronic effects, including largely reversible responses, such as rashes and irritations, as well as irreversible toxic and

(a) Pacific Northwest Laboratory is operated by Battelle Memorial Institute for the U.S. Department of Energy under Contract DE-AC06-76RLO 1830. 
carcinogenic effects. These indoor contaminants are emitted from a large variety of materials and substances that are widespread components of everyday life.

Asbestos, combustion gases, formaldehyde, and radon have been the focus of indoor air quality studies for some time. However, the understanding of complex mixtures of these and other commoniy available chemicals is onty in its infancy. As an example, environmental tobacco smoke contains over 5000 different chemicals. Simitariy, for the large number of volatile organics that emanate from a variety of consumer products, building materials, and furnishings, researchers are in the very early stages of quantitative study to relate specific organics to specific material sources. In addition, there are a variety of biogenic contaminants potentially available in public buildings that can have a wide variety of effects on people. It can be difficult to identify health and well-being problems associated with specific compounds since actual exposures are to the various combinations of mixtures of these chemicals.

This summary report presents the best available information on the health effects associated with each of the contaminants listed in Table 1.1. This information was obtained by conducting a comprehensive 1 iterature search for each of the chemicals. As part of this review, PNL used three active, professionally maintained and peer-reviewed, on-line chemical databases to locate the latest health effects information on each contaminant. These databases were the U.S. Environmental Protection Agency (EPA) Integrated Risk Information System (IRIS), the National Library of Medicine Hazardous Substance Data Bank (HSDB), and the National Institute for Occupational Safety and Health (NIOSH) Registry of Toxic Effects of Chemicals (RTECS).

This report discusses only those contaminants that have been measured in the indoor air of a public building or measured (significant concentrations) in test situations simulating indoor air quality and that have a significant hazard rating associated with them. Most of the research on indoor air contaminants has been done on public buildings. Because public buildings are similar to commercial buildings in their construction and functions, the health effects information in this report should be applicable to the 
IABLE 1.1. Contaminants Examined in Health Effects Study

$\begin{array}{ll}\text { Benzene } & \text { Formaldehyde } \\ \text { Benzo[a]pyrene } & \text { Methyl ethyl ketone } \\ \text { Biogenic particles } & \text { Nitrogen oxides } \\ \text { n-butyl acetate } & \text { Octane } \\ \text { Carbitol } & \text { Octene } \\ \text { Carbon dioxide } & \alpha \text {-pinene } \\ \text { Carbon monoxide } & \text { Polychlorinated biphenyls } \\ \text { Carbon tetrachloride } & \text { Propyl benzene } \\ \text { Chlorofluorocarbons } & \text { Radon/radon daughters } \\ \text { Chloroform } & \text { Styrene } \\ \text { Decane } & \text { Synthetic fibers (fiber glass and } \\ \text { Dichlorobenzene } & \text { cellulose) } \\ \text { Dichloromethane } & \text { Tetrachloroethylene } \\ \text { Dodecane } & \text { Toluene } \\ \text { Environmental tobacco } & 1,1,1 \text {-trichloroethane } \\ \text { Smoke } & \text { Trichloroethylene } \\ \text { 2-ethoxy ethyl acetate } & 1,2,4 \text {-trimethylbenzene } \\ \text { Ethyl benzene } & \text { Undecane } \\ \text { Ethylene glycol } & \text { xylene }\end{array}$

commercial sector as well. The contaminants identified (in the literature reviewed) in building materials, but not found in the building studies examined, include cumene, chlorobenzene, nonane, iso-octane, iso-nonane, isodecane, tetrachloroethane, mesitylene, $n$-hexane, 3-carene, propanol, 2-butanone, acetone, diethylbenzene, hexanol, d-limonene, vinyl chloride, butanol, $n$-heptane, $n$-heptene-1, 3-pentanol, and ethyl acetate. These are only a few of the host of other potential hazardous contaminants that may be found in the indoor air of public buildings.

\subsection{LIMITATIONS TO THE DATA}

The information presented in this document represents the most recent information on health effects of the chemicals discussed; however, there are several 1 imitations to the data and information presented. First, in many 
cases the health effects data was determined by exposing animals to fairly high doses of the chemicals. This requires that the data be extrapolated back down to the normally low doses of the chemical to which a person will be exposed in commercial building indoor air environments. This extrapolation process is complicated by the assumptions that have to be made regarding whether there is a threshold effect or not for the chemical and whether the data are linear at low doses, or how it should be extrapolated for these low doses. This data interpretation process is further complicated by the fact that the data has to be translated from the effects on animals to the effects on humans.

The concentrations of the contaminants discussed in this report are typically several times lower in commercial buildings than those found in occupational settings. Little is known about the health effects associated with exposure at low concentrations over long periods of time. Preliminary research is being done regarding the effects of volatile organics. However, less information is available about other potential indoor air pollutants such as biological contaminants. Furthermore, these chemicals often exist in the indoor air environment in the form of complex mixtures, which, in many cases, causes the chemicals to behave differently in terms of the effects on human health than they do when considered separately. Although the health effects studies of the individual chemical compounds found in indoor air are useful in understanding and predicting the risks from these chemicals, there are serious limitations to extrapolating the results from single chemical studies to the actual environmental exposure of humans. The toxicological study of complex mixture sets representing the circumstance of actual exposure in typical commercial building situations should be performed to more accurately examine the combined or synergistic effects of the actual chemical-mixture set to which the public is being exposed.

Normally, the assumptions made regarding the development of the health effect parameters and factors presented in this document are conservative (i.e., they err on the side of overpredicting adverse effect). Thus, while research continues on health effects of the host of chemicals and complex chemical mixtures that potentially exist in buildings, these parameters and 
factors (which should be updated regularly as research progresses) can be used to provide estimates of the health impact and risk for particular building situations. In making building-specific health/risk assessments, specific building conditions should be determined (i.e., monitored/calculated) as accurately as possible, to consider the most realistic set of chemicals, mixture combinations, concentrations of chemicals, exposure times, and physical conditions.

Despite the limitations to the data, the health effects information presented here should be considered the best available data. It should prove adequate to conduct risk assessments (at least for individual pollutants) and can serve as a pointer to the appropriate literature for further information. 
.

- 


\subsection{INTERPRETING THE HEALTH EFFECTS INFORMATION}

The health effects information available for each contaminant varies widely. A vast amount of information is available on some of the contaminants, such as polychlorinated biphenyls (PCBs) and formaldehyde, while little or no information is available on others, such as $\alpha$-pinene and octene. Although for some contaminants the information provided in this report may be limited, it should be considered the best available at this time.

In this chapter, the major concepts and terms required for interpreting the information in Table S.I and in the following chapters are explained. A glossary of terms appears in Section 11 of this report.

\subsection{CHEMICAL DATA}

This report presents chemical data for most of the contaminants, including molecular formula, vapor pressure, flash point, and common synonyms for the chemical. The molecular formula indicates the molecular structure of the chemical. Vapor pressure is a measure of a chemical's volatility, i.e., how easily it evaporates. It is expressed in millimeters of mercury ( $\mathrm{mm} \mathrm{Hg}$ ). The higher the vapor pressure, the more volatile the substance. The flash point (FP) is an indication of the fire and explosion hazard posed by a chemical. The $f l a s h$ point is the lowest temperature at which vapors of a combustible substance ignite in air when exposed to flame. Materials with FPs below 100 degrees are dangerous because a spark or static electricity can cause a fire or explosion. If a chemical does not have a flash point it means the material is nonflammable. In the list of synonyms for a compound, the most common name is given first.

\subsection{TOXIC EFFECTS}

Toxic effects can result from acute exposure (a single, brief contact) to some chemicals; others only have toxic effects with chronic exposure (repeated or prolonged contact). Some cause effects in both cases. Similarly, the effects of contaminants can be acute and chronic. Acute effects usually occur soon after exposure, although, in some cases, they may 
be delayed. For some chemicals, acute effects are short-term and reversible, depending on the concentration. More intense acute exposures can result in permanent damage or even death. Chronic effects do not appear until some time after exposure, in some cases years later, and they are usually permanent and irreversible.

There are several possible exposure pathways. For example, contaminants can enter the body through the skin, or they can be ingested and inhaled. In this report, the emphasis is placed on health effects associated with the airborne exposure pathway, since this is likely to be the most dominant pathway of exposure in commercial buildings. Effects can vary with the exposure pathway, and can be localized or systemic. Local effects--for example, skin irritation--occur at the point of contact. A systemic reaction occurs when the chemical is absorbed into the blood stream. Most chemicals that produce systemic toxicity do not cause a similar degree of toxicity in all organs.

Sax and Lewis have developed a general hazard rating scale that designates chemicals as being or having low (1), medium (2), or high (3) toxicity. This hazard rating relies on two numerical measures: the lethal concentration(50) (LC50) and the lethal dose(50) (LD50). The LC50 is a calculated concentration of a chemical in air to which exposure for a specific length of time is expected to cause death in $50 \%$ of a defined experimental animal population. The LD50 is the dose of a chemical that has been calculated to cause death in $50 \%$ of a defined animal population. The rating scale is shown in Table 2.1.

IABLE 2.1. Sax and Lewis' Chemical Hazard Rating Scale

\begin{tabular}{|c|c|c|}
\hline $\begin{array}{l}\text { Hazard } \\
\text { Rating }\end{array}$ & $\begin{array}{r}\mathrm{LD50} \\
(\mathrm{mg} / \mathrm{kg}) \\
\end{array}$ & $\begin{array}{r}\text { LC50 } \\
(0 \mathrm{pm}) \\
\end{array}$ \\
\hline $\operatorname{Low}(1)$ & $4,000-40,000$ & $4,000-40,000$ \\
\hline Medium(2) & $400-4,000$ & $100-500$ \\
\hline High(3) & $<400$ & $<100$ \\
\hline
\end{tabular}


The letter $D$ is used to indicate cases where the data are unavailable or insufficient to indicate a relative rating. In most cases, a $D$ is assigned when only in vitro mutagenic or experimental reproductive data are available.

A Threshold Limit Value (TLV) for each chemical is given whenever available. The TLVS are recommended guidelines for occupational exposure to airborne contaminants pub]ished by the American Conference of Governmental Industrial Hygienists (ACGIH). The value is specified as a time-weighted average (TWA) representing the average concentration (in milligrams per cubic meter) for an 8-hour workday and a 40-hour work week to which nearly all workers may be repeatedly exposed, day after day, without adverse effect. Whenever available, the OSHA-enforced short-term exposure limit (STEL) is also given. The STEL is the maximum concentration of a toxic chemical to which a worker should be exposed during a specified period of time, usualiy 15 minutes. Carcinogens are thought to be non-threshold chemicals, to which no exposure can be presumed to be without some risk of adverse effect. For some chemicals, other EPA exposure levels are reported (see Glossary). These may include 1) no observed adverse effect level (NOAEL), 2) no observed effect level (NOEL), 3) lowest observed adverse effect level (LOAEL) or lowest effect level (LEL), and 4) frank effect level (FEL).

The EPA provides risk assessment information in the form of oral and inhalation reference doses (RfDs) for chronic noncarcinogenic health effects. A reference dose is an estimate, with uncertainty spanning perhaps an order of magnitude, of a daily exposure to the human population (including sensitive subgroups) that is likely to be without appreciable risk of deleterious effects during a lifetime. In most cases, only an oral reference dose (RfDo) is available. This gives some sense of the relative toxicity of the compound but is not directly applicable to inhalation exposure. EPA work groups are currently conducting risk assessments to determine inhalation reference doses (RfDs) for several toxins.

\subsection{CARCINOGENICITY}

The EPA has a weight-of-evidence classification system for human carcinogenicity (see Table 2.2). The classification indicates the extent to 
TABLE 2.2. EPA Carcinogenic Weight-of-Evidence Classifications

Category

Group

A

$B 1$

B2

C

D

E
Estimate of Cancer Risk

Known human carcinogen

Probable carcinogen

Probable carcinogen

Possible carcinogen

Carcinogenic potential

Not carcinogenic
Type of Data

Supporting Category

Human

Human

Animal

Animal

Unknown

Human or animal

which the available biomedical data, both human and animal, support the hypothesis that a substance causes cancer in humans. For example, Class A contaminants, such as benzene and radon, are known to be hazardous human carcinogens. Class $D$ substances cannot be classified based on current data. The EPA classification is given whenever available.

The EPA provides carcinogenicity risk assessment information in the form of inhalation slope factors and inhalation unit risks. These numbers, also known as Carcinogenic Potency Factors, indicate the increased number of cancers associated with a particular dose or exposure to a contaminant. Risks are generally expressed as numbers from zero to one: $E-4$ indicates a risk of 1 in 10,000, E-5 indicates 1 in 100,000, and E-6 indicates 1 in 1,000,000. For example, the inhalation slope factor associated with exposure to benzene is $2.9 \mathrm{E}-2 / \mathrm{mg} / \mathrm{kg} /$ day. This means that there will be 2.9 cancers per hundred people exposed to an average lifetime intake of one milligram of benzene (dose) per kilogram of body weight per day.

\subsection{REPRODUCTIVE AND DEVELOPMENTAL EFFECTS}

Effects on pregnant women (maternal effects) are presented, if available, as is any evidence regarding genetic and developmental effects (effects on the fetus) of exposure. Reproductive toxins may affect the reproductive organs or the related endocrine system, causing adverse effects such as changes in sexual behavior, fertility, and pregnancy outcomes. Developmental toxicity effects may result from exposure of either parent to a 
chemical prior to conception, during prenatal development, or postnatally to the time of sexual maturation. Embryotoxicity and fetotoxicity both designate adverse effects to the unborn organism, human or otherwise, including malformations, altered growth, and in utero death. The distinction between the two terms has to do with the stage of development at which exposure is toxic. Teratogens cause structural defects that alter the development of the organism causing fetal abnormalities. 


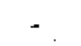




\subsection{VOLATILE ORGANIC COMPOUNDS}

The term volatile organic compound (VOC) refers to a class of carbonbased chemicals that evaporate easily, thus giving off vapors that can be inhaled. Indoor sources of VOCs are numerous and include construction materials, furnishings, combustion of cooking and heating fuels and tobacco, and human metabolism. Semivolatile compounds, which evaporate less easily, include pesticides, PCBs, polyaromatic hydrocarbons (PAHs), and plasticizers used in the manufacture of plastic and foam products.

Many volatile organics are toxic. Because vocs are fat-soluble, they are easily absorbed into the blood stream through the lungs. Both chronic and acute health effects may result from VOC exposure. Acute effects caused by VOCs include eye, nose and throat irritation; headaches, depression, irritability, and forgetfulness; and general malaise. Some VOCs, such as the aldehydes, have strong unpleasant odors that can cause stress. Chronic health effects, including cancer, may be caused by long-term exposure. Studies of workers exposed to organic solvents (acetone, benzene, toluene, ethyl acetate, butyl acetate, xylene, gasoline, and turpentine) have found a higher incidence of chronic bronchitis and a lower volume of expiratory air than in normal control subjects. In smokers, the incidence was higher than nonsmokers of exposed and nonexposed groups.

Only a few of the thousands of VOCs that are likely to be found indoors have been tested for carcinogenic activity. Of these, benzene and methylene chloride (dichloromethane) are recognized human carcinogens. Others, such as chloroform, trichloroethylene, carbon tetrachloride, and p-dichlorobenzene, have been found to cause cancer in animals, and may do so in humans. Vocs can also be mutagenic (cause cell mutation). Studies have found that central nervous system defects were more common in children of mothers exposed to organic solvents and dusts during pregnancy. Occupational studies have found severe brain abnormalities in children whose mothers had been exposed to the solvents toluene, xylene, and White Spirit during the manufacture of rubber products. 
Organic compounds can be grouped according to structural similarities. Examples of organic compound types and their sources are shown in Table 3.1. The volatile organics discussed in this chapter are set in italics and are discussed by class, because similar compounds can have similar health effects. Thus, in cases where little information is available regarding a specific contaminant, sometimes effects can be estimated based on the effects caused by other members of the class. As mentioned previously, this report examines only those compounds that have been found in the indoor air of public access buildings or are emitted by building materials related to energy conservation. PCBs are discussed in a later chapter.

\subsection{ALIPHATIC AND OXYGENATED ALIPHATIC HYDROCARBONS}

Aliphatic hydrocarbons are often petroleum derivatives, such as naphthas, paraffins, mineral spirits, $n$-hexane, and kerosene. The direct aspiration of paraffins with carbon numbers $C_{6}$ to $C_{16}$ into the lungs may cause chemical pneumonitis (inflammation of the lungs), pulmonary edema, and hemorrhaging.

\section{1 .1 n-Butyl Acetate $(2.2 .2)^{(a)}$}

Synonyms: buty 1 acetate, 1-butyl acetate, and butyl ethanoate

Butyl acetates are irritants and narcotic in high concentrations. The primary target organs for n-butyl acetate are the eyes, skin, and respiratory system. n-butyl acetate has no notable systemic toxicity, but its vapor causes irritation of the eyes and nose. Occasional complications include gastrointestinal hemorrhage, kidney damage, cardiac failure, and pulmonary edema. Inhalation of paint thinner containing acetate esters, including butyl acetate, causes drunkenness and hallucination in human subjects. Blood chemistry tests have indicated anemia in workers exposed to a variety of fat solvents, including butyl acetate.

$n$-butyl acetate is normally first noticeable to humans at concentrations of $300 \mathrm{ppm}$ in air and is objectionable at concentrations of 3,300 ppm.

(a) The numbers in parentheses correspond to the section numbers in volume 2 of this report, in which each chemical is discussed in detail. 
TABLE 3.1. Examples of Organic Compounds and Sources

Pollutant Type

Aliphatic and

Oxygenated

Aliphat ic

Hydrocarbons

genated

Hydrocarbons

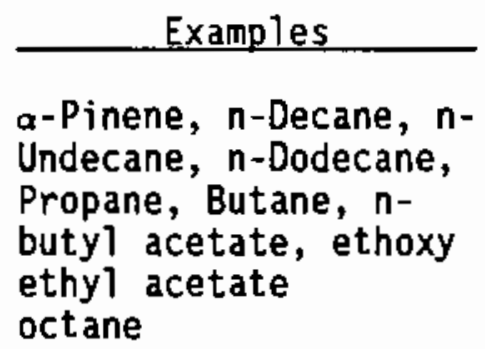

Chloroform, Methyl

ChToroform,

Dichloromethane, PCBs, 1,1,1-trichloroethane,

Trichloroethylene

Tetrachloroethylene, chlorobenzene,

Dichlorobenzene

carbon tetrachloride

Xylene, Ethyl benzene, Trimethylbenzene, Ethyl toluene, Propyl benzene, Benzene, Styrene, Toluene

Aromatic
Hydrocarbons

Alcohols

Ketones

ATdehydes
Ethanol, Methanol

Acetone, Diethyl Ketone, Methyl Ethyl Ketone

Formaldehyde, Nonanal
Examples of Indoor Sources

Cooking and heating fuels, aerosol propellants, cleaning compounds, paints, carpet, moldings, particle board, refrigerants, lubricants, flavoring agents, perfume base

Aerosol propellants, fumigants, pesticides, refrigerants, adhesives, caulk, paint, linoleum tile, carpet, latex paint, and degreasing, dewaxing, and dry cleaning solvents

Paints, varnishes, glues, enamels, lacquers, cleaners, adhesives, molding, insulation, linoleum tile, carpet

Lacquers, varnishes, polish removers, adhesives

Lacquers, varnishes, polish removers, adhesives, cleaners

Fungicides, germicides, disinfectants, artificial and permanent-press textiles, paper, particle board, cosmetics, flavoring agents

However, throat irritations in human subjects are noticed at 200-ppm concentrations, and become quite severe at $300 \mathrm{ppm}$. Mild irritation to the eyes and nose has been reported after a brief exposure to 200- to 300-ppm concentrations. 
Persons with skin, kidney, and chronic respiratory disease may be at an increased risk from butyl acetate exposure.

\subsubsection{Decane (2.2.5)}

Synonyms: $n$-decane

No specific studies involving the toxicology of decane were found. However, based on the toxicological evidence for other hydrocarbons, the most serious toxic effect following ingestion of decane is likely to be aspiration pneumonitis (inflammation of the lungs). Aspiration of hydrocarbons may also result in transient central nervous system depression or excitement. Secondary effects may include hypoxia (oxygen deficiency), infection, formation of hernias in the lung, and chronic lung dysfunction. Inhalation may result in euphoria, cardiac dysrhythmias, respiratory arrest, and central nervous system toxicity.

The symptoms of decane exposure are coughing, choking, abnormally fast and difficult breathing, cyanosis, and roles. Coughing up blood and pulmonary edema may occur following ingestion and aspiration. Transient central nervous system excitation followed by depression may occur, especially after inhalation. Liver and kidney damage may occur following ingestion.

Less than 1 millileter (mi) of some hydrocarbons, when directly aspirated into the lungs, has produced severe inflammation of the Tungs.

\subsubsection{Dodecane (2.2.8)}

Synonyms: adakane 12, bihexyl, dihexyl, n-dodecan, and duodecane

The amount of information available regarding the toxicological effects of dodecane is very limited, but animal studies suggest that dodecane is not highly toxic. However, studies indicate dodecane as a possible potentiator of skin tumors caused by exposure to benzo[a]pyrene.

\subsubsection{2-Ethoxy Ethyl Acetate (2.2.9)}

Synonyms: cellosolve acetate, 2-ethoxyethanol acetate, ethylene glycol ethyl ether acetate, ethylglycol acetate, and oxytol acetate 
The amount of information regarding the toxicological effects of 2-ethoxy ethyl acetate is very limited. No studies of human toxicology were found. However, animal studies suggest that 2-ethoxy ethyl acetate is moderately toxic by ingestion and mildly toxic by skin contact and inhalation. 2-ethoxy ethyl acetate has been found to be a skin and eye irritant and is an experimental teratogen (causes fetal abnormalities).

\section{1 .5 Octane (2.2.13)}

Synonyms: None

The amount of toxicological information available for octane is very limited. No specific studies involving the human toxicology of octane were found. Octane is rated moderately toxic, having approximately 1.2 to 2 times the potency of heptane, but it does not appear to exhibit the central nervous system effects that the two lower homologues (hexane and heptane) do. Orally, octane may be more toxic than its lower homologues. If the material is aspirated into the lungs, it may cause rapid death due to cardiac arrest, respiratory paralysis, and asphyxia. There may be epileptiform seizures months after an acute episode of octane exposure. Irritation of the upper and lower respiratory tract and internal organ damage has also been described. Direct aspiration of paraffins with carbon numbers $C_{6}$ to $C_{16}$ into the lungs may cause chemical pneumonitis (inflammation of the lungs), pulmonary edema, and hemorrhaging. Pathological examination of tissues from fatal cases of octane exposure shows evidence of widespread microhemorrhagic phenomena.

One animal study found that inhalation of octane aggravated the cardiovascular phenomena caused by carbon monoxide and, al though hydrocarbons are central excitants, further degraded electroencephalographic (EEG) activity.

\section{1 .6 a-Pinene (2.2.14)}

Synonyms: 2-pinene, Acintene A, and 2,6,6-trimethyl bicyclo (3.1.1) 2-Hept-2-ene

The amount of toxicological information available for $\alpha$-pinene is very limited. No specific studies involving human toxicology of $\alpha$-pinene were found. $\alpha$-pinene can be absorbed through the skin, lungs, and intestine. In significant quantities, it is considered a deadly poison by inhalation and 
moderately toxic by ingestion. Aspiration or systemic absorption may lead to pulmonary edema and inflammation of the lung. $\alpha$-pinene is an eye, mucous membrane, and severe skin irritant, and can cause skin eruption, gastrointestinal tract irritation, delirium, ataxia (loss of coordination), kidney damage, and coma. Inhalation can cause palpitation, dizziness, nervous disturbances, chest pain, bronchitis, and kidney disease. It can also cause benign skin tumors from chronic contact.

$\alpha$-pinene has essentially the same toxicity as turpentine.

\section{1 .7 Undecane (2.2.23)}

Synonyms: hendecane and $n$-undecane

The amount of information regarding the toxicological effects of undecane is very limited. No studies of human toxicology were found. The direct aspiration of paraffins with carbon numbers $C_{6}$ to $C_{16}$ into the lungs may cause chemical pneumonitis (inflammation of the lungs), pulmonary edema and hemorrhaging.

\subsection{HALOGENATED HYDROCARBONS}

Chlorinated hydrocarbons are used as solvents for paints and varnishes because they are nonflammable, but most are known to be very toxic, cause liver damage and contain carcinogens. For example, methylene chloride (dichloromethane), a common ingredient in paint strippers, forms carbon monoxide in the body and can cause cancer.

\subsubsection{Carbon Tetrachloride (2.2.3)}

Synonyms: acritet, benzinoform, carbona, carbon chloride, carbon tetrachloride, freon-10, Halon-104, methane tetrachloride, tetrachloromethane, perchloromethane, tetrafinol, tetraform, and tetrasol

Carbon tetrachloride is toxic by all routes of exposure. Its vapor is a narcotic and causes severe damage to the liver and kidneys. Liver damage occurs more often after ingestion than after inhalation and can be permanent even from acute exposure. Individuals who have experienced short-term 
overexposure may experience delayed effects (up to 2 to 3 days) that inciude damage to the heart, Tiver, and kidneys. Irregular heartbeat and episodes of cerebellar dysfunction have been reported.

Toxicity via inhalation has been noted following a 30-minute exposure to $160 \mathrm{ppm}$. Systemic toxicity may follow dermal exposure. In humans, the majority of fatalities have been the result of acute kidney damage with secondary cardiac failure and have occurred after exposure for $1 / 2$ to 1 hour to concentrations of 1,000 to $2,000 \mathrm{ppm}$.

Carbon tetrachioride is a probable human carcinogen based on carcinogenicity in rodents. There is inadequate human carcinogenicity data available, although there have been three case reports of liver tumors developing after carbon tetrachloride exposure and several studies have suggested that workers who have used carbon tetrachloride may have an excess risk of cancer.

Alcohol has been clearly shown to potentiate the toxicity of carbon tetrachloride.

Risk Assessment: The oral reference dose (RfDo) for carbon tetrachloride is $7 \mathrm{E}-4 \mathrm{mg} / \mathrm{kg} /$ day, with the critical effect being liver lesions. There is no inhalation reference dose (RfDi) available at this time.

The inhalation slope factor for carbon tetrachloride is $1.3 \mathrm{E}-1 /$ $\mathrm{mg} / \mathrm{kg} /$ day. The inhalation unit risk is $1.5 \mathrm{E}-5 / \mu \mathrm{g} / \mathrm{cu} . \mathrm{m}$. The extrapolation method used was the linearized multistage procedure using extra risk. The air concentrations at specified risk levels are:

\begin{tabular}{lll} 
Risk Leve & & Concentration \\
\hline$E-4(i$ in 10,000$)$ & $7 E+0 / \mu \mathrm{g} / \mathrm{cu} . \mathrm{m}$ \\
$\mathrm{E}-5(1$ in 100,000$)$ & $7 \mathrm{E}-1 / \mu \mathrm{g} / \mathrm{cu} . \mathrm{m}$ \\
$\mathrm{E}-6$ (I in $1,000,000)$ & $7 \mathrm{E}-2 / \mu \mathrm{g} / \mathrm{cu} \cdot \mathrm{m}$
\end{tabular}




\subsubsection{Chloroform (2.2.4.1)}

Synonyms: formyltrichloride, methanetricholoride, methenultrichloride, methyltrichioride, R20 (refrigerant), TCM, trichloroform, and trichloromethane.

Chloroform is classified as moderately toxic. Exposure may occur by oral, inhalation, or dermal routes. Chloroform is a gastrointestinal irritant, a central nervous system and cardiac depressant, and can cause delayed liver and kidney damage. Conjunctivitis and spasmodic winking may occur from exposure to vapors of chloroform. Respiratory depression, chemical pneumonitis (inflammation of the lungs), and pulmonary edema may occur. Central nervous system depression, headache, and anorexia have been noted from significant exposures to choloroform. Kidney and liver damage and frequent urination have been reported and liver death has occurred 10 to 48 hours postingestion. Chloroform has caused rapid death attributable to cardiac arrest.

Signs of chloroform poisoning in humans include a characteristic sweetish odor on the breath, dilated pupils, cold and clammy skin, initial excitation alternating with apathy, loss of sensation, loss of motor functions, prostration, unconsciousness, and eventual death.

Chloroform may be embryotoxic, and it is classified as a probable carcinogen based on increased incidence of several tumor types in rodents. The human carcinogenicity data are inadequate, and there are no epidemiologic studies of chloroform itself. Chloroform is formed from the interaction of chlorine with organic material found in water. Several ecological and case studies of populations consuming chlorinated drinking water show small significant increases in the risk of rectal bladder or colon cancer on an intermittent basis. However, al though chloroform was the major chlorinated organic, many other suspected carcinogens were also present in these water supplies.

Substances that potentiate the toxic effects of chloroform are methy] n-butyl ketone, alcohol, carbon tetrachloride, chlordecone, DDT, and phenobarbital. 
The half-life for chloroform in air is 80 days.

Risk Assessment: The oral reference dose (RfDo) for chloroform is IE-2 $\mathrm{mg} / \mathrm{kg} /$ day, with the critical effect being fatty cyst formation in the liver.

The inhalation slope factor for chloroform is $8.1 \mathrm{E}-2 / \mathrm{mg} / \mathrm{kg} / \mathrm{day}$. The inhalation unit risk is $2.3 \mathrm{E}-5 / \mu \mathrm{g} / \mathrm{cu} . \mathrm{m}$. The extrapolation method used was the linearized multistage procedure, using extra risk. The air concentrations at specified risk levels are:

\begin{tabular}{lll} 
Risk Leve & & Concentration \\
\hline$E-4(1$ in 10,000$)$ & & $4 / \mu \mathrm{g} / \mathrm{cu} . \mathrm{m}$ \\
$\mathrm{E}-5(1$ in 100,000$)$ & $4 \mathrm{E}-1 / \mu \mathrm{g} / \mathrm{cu} \cdot \mathrm{m}$ \\
$\mathrm{E}-6$ (1 in $1,000,000)$ & $4 \mathrm{E}-2 / \mu \mathrm{g} / \mathrm{cu} \cdot \mathrm{m}$
\end{tabular}

\subsubsection{2-Dichlorobenzene (2.2.6)}

Synonyms: 0-dichlorobenzene, chloroben, DCB, o-Dichlor Benzol, Dilantin DB, Dilat in DB, Dizene, Dowtherm E, orthodichlorobenzene, orthodichlorobenzol, Termitki1, and ODB

No human toxicological studies of 1,2-dichlorobenzene were found. Animal studies have found indications of liver damage, increased liver, spleen and kidney weights, and slight decreases in blood counts due to exposure to 1,2-dichlorobenzene. Rodent studies found neither teratogenic nor fetotoxic effects from inhalation, but did find significant decreases in maternal body weight in some cases. There is one reported case in which a 55-year-old female received a nonoccupational, chronic repeated inhalation exposure (1 to 2 liters/year) to vapors from use of solution to clean clothes, resulting in acute myeloblastic leukemia.

Risk Assessment: The oral reference dose (RfDo) is $9 E-2 \mathrm{mg} / \mathrm{kg} / \mathrm{day}$, with no adverse critical effects observed. There is no chronic inhalation reference dose ( $R f D i$ ) available at this time. 


\subsubsection{Dichloromethane (2.2.7)}

Synonyms: methylene chloride, methane dichloride, DCM, 1,1-dichloromethane, freon-30, methylene bichloride, and methylene dichloride

Chronic oral exposure to dichloromethane can result in liver damage. Dichloromethane retained in inhalation is metabolized to carbon monoxide, which reduces the oxygen-carrying capacity of the blood. At relatively high exposures, the resulting oxygen starvation may pose a health hazard. The human carcinogenicity data is inadequate, but dichloromethane is classified as a probable human carcinogen based on increased cancer incidence in rodents. This assessment information may change in the near future depending on the outcome of further review now being conducted by the EPA CRAVE Work Group.

Risk Assessment: The RfD for chronic orat exposure (RfDo) for dichloromethane is $6 \mathrm{E}-2 \mathrm{mg} / \mathrm{kg} /$ day, with liver toxicity as the critical effect. The reference dose for chronic inhalation exposure ( $R f D i$ ) is not available at this time.

The inhalation slope factor for dichloromethane is $7.5 \mathrm{E}-3 / \mathrm{mg} / \mathrm{kg} / \mathrm{day}$. The extrapolation method used was the linearized multistage procedure, with extra risk considered. The inhalation unit risk is $4.7 \mathrm{E}-7 / \mu \mathrm{g} / \mathrm{cu} . \mathrm{m}$. An inhalation slope factor is not available. The air concentrations at specified risk levels are:

$\begin{array}{lll}\text { Risk Leve } & \text { Concentration } \\ \mathrm{E}-4(1 \text { in } 10,000) & 2 \mathrm{E}+2 / \mu \mathrm{g} / \mathrm{cu} . \mathrm{m} \\ \mathrm{E}-5(1 \text { in } 100,000) & 2 \mathrm{E}+1 / \mu \mathrm{g} / \mathrm{cu} . \mathrm{m} \\ \mathrm{E}-6 \text { (1 in } 1,000,000) & 2 / \mu \mathrm{g} / \mathrm{cu} . \mathrm{m}\end{array}$

\subsubsection{Tetrachloroethylene (2.2.18)}

Synonyms: Perchloroethylene, carbonbichloride, carbordichloride, PCE, PER, PERC, Perchlor, PERK, 1,1,2,2-tetrachloroethylene, and tetrachl oroethene

Tetrachloroethylene is toxic by ingestion, inhalation, or dermal exposure. Excessive exposure to tetrachloroethylene has resulted in effects 
on the centra] nervous system (CNS), mucous membranes, eyes and skin, and, to a lesser extent, on the lungs, liver, and kidneys. The effects most frequently noted have been on the nervous system: unconsciousness, dizziness, headache, vertigo (illusion of spinning), or light CNS depression have occurred in many instances after occupational exposures. Inhalation abuse of typewriter correction fluid has been reported.

Studies have shown that absorption of perchloroethylene (PCE) through the skin, from vapor exposure or from partial body immersion, is minimal in comparison to the oral and inhalation routes of exposure. PCE is rapidiy and virtually completely absorbed into the body from the gastrointestinal tract and PCE in vapor form in air is readily absorbed through the lungs into the blood.

Several studies of the effects of prolonged exposure to perchloroethylene vapors on human volunteers are available. Prolonged exposure can result in early signs of CNS depression, and alterations in liver function in persons exposed to unknown concentrations of PCE over extended periods have been reported by a number of investigators. There is a case report of a 6-week-old breast-fed infant with obstructive jaundice and an enlarged liver. Tetrachloroethylene was detected in milk and blood.

Tetrachloroethylene is among the chemicals being evaluated by the EPA for evidence of human carcinogenic potential. This does not imply that it is necessarily a carcinogen.

Repeated PCE exposure effects might be exacerbated by simultaneous administration of either alcohol or diazepan.

Risk Assessment: The chronic orat exposure reference dose (RfDo) for terachloroethylene is $1 \mathrm{E}-2 \mathrm{mg} / \mathrm{kg} /$ day, with the critical effect being 1 iver toxicity in mice and weight gain. The NOAEL is $20 \mathrm{mg} / \mathrm{kg} / \mathrm{day}$, and the LOAEL is $100 \mathrm{mg} / \mathrm{kg} /$ day. A chronic inhalation reference dose (RfDi) is not available at this time. 


\subsubsection{1,1,1-Trichloroethane (2.2.20)}

Synonyms: methylchloroform, Aerothene TT, chlorothene, Inhibisol, methyltrichloromethane, Strobane, a1pha-T, 1,1,1-TCE, and alphatrichloroethane

1,1,1-trichloroethane is one of the least toxic of the chlorinated hydrocarbons used as a solvent. Trichloroethane is a central nervous system and respiratory depressant, and a skin and mucous membrane irritant. Exposure can cause minimal impairment of coordination, headache and lassitude, and, during exposure, may cause impairments to psychophysiological functions, e.g., reaction time, perceptual speed and manual dexterity. Prolonged or repeated contact with skin results in transient redness and slight irritation, owing to the defatting action of the solvent. Some cases have also been observed in which repeated skin contact will cause a serious dermatitis characterized by skin cracking and infection.

A concentration of $100 \mathrm{ppm}$ is the apparent odor threshold for 1,1,1trichloroethane. Concentrations of 350 to $500 \mathrm{ppm}$ produce slight changes in perception and obvious odor. A concentration of 1,000 ppm produces disturbance of equilibrium, and 1,900 to 2,650 ppm produces 1 ightheadedness and irritation of the throat. Concentrations above 5,000 ppm, which is the onset of central nervous system depression, are possibly life-threatening.

1,1,1-trichloroethane is not classified as to human carcinogenicity because there is no reported human data, and animal studies are considered inadequate. However, an isomer, 1,1,2-trichloroethane, is carcinogenic in mice, inducing liver cancer and pheochromocytomas in both sexes.

Dichloroethanes, tetrachloroethanes, and hexachloroethanes also produced liver cancer in mice and other types of neoplasms (abnormal growths) in rats. 1,4-dioxane, a known animal carcinogen causing liver and nasal tumors, is a contaminant of technical-grade $1,1,1$-trichloroethane.

Risk Assessment: The chronic oral exposure reference dose (RfDo) for 1,1,1-trichloroethane is $9 E-2 \mathrm{mg} / \mathrm{kg} /$ day, with no critical adverse effects listed. The NOAEL is $500 \mathrm{ppm}$ (air), and the LOAEL is $650 \mathrm{ppm}$ (air). 
There is no quantitative estimate of carcinogenic risk for either the oral or inhalation exposure route.

\subsubsection{1,1,1-Trichloroethylene (2.2.21)}

Synonyms: acetylenetrichloride, Benzinol, 1-chloro-2,2,-dichloroethylene, Circosoiv, 1,1-dichloro-2-chloroethylene, ethyinyltrichloride, ethylenetrichloride, Lanadin, Narcogen, TCE, TRI, Triasol, trichlorethene, trichloroethene, 1,1,2-trichloroethylene, 1,2,2trichloroethylene, Tri-Clene, Triol, Vitran, and Westrosol

Exposure to trichloroethylene vapors causes irritation of the mucous membranes in the eyes and nose. Skin contact produces severe erythema (skin redness) and blistering, followed by scaling. Ingestion causes a burning sensation in the mouth, nausea, vomiting, and abdominal pain. Chronic exposure, as in solvent abusers, can produce weight loss, nausea, fatigue, visual impairment, dermatitis, and, rarely, jaundice. Temporary loss of tactile sense and paralysis of the fingers may occur after direct contact with the solvent. Prolonged occupational exposure to trichloroethylene has been associated with impairment of peripheral nervous system function and persistent neuritis (nerve inflammation).

Workers exposed at concentrations averaging about $10 \mathrm{ppm}$ complained of headache, dizziness, and sleepiness. Eye irritation is reported at $160 \mathrm{ppm}$.

Trichloroethylene is classified as a probable human carcinogen. Trichloroethylene is on the CAG 1ist. (a) EPA has indicated that it intends to

(a) The Carcinogen Assessment Group (CAG), Office of Health and Environmental Assessment in EPA's Research and Development Office, has prepared a list of chemical substances for which substantial or strong evidence exists showing that exposure to these chemicals, under certain conditions, causes cancer in humans, or can cause cancer in animal species, which, in turn, makes them potentially carcinogenic in humans. Substances are placed on the CAG Tist only if they have been demonstrated to induce malignant tumors in one or more animal species or to induce benign tumors that are generally recognized as early stages of malignancies, and/or positive epidemiologic studies indicated they were carcinogenic. 
add TCE to the list of hazardous air pollutants regulated by emission standards under section 112 (b)(1)(A) of the Clean Air Act if current studies warrant emission standards.

Dilation of the blood vessels and malaise occur in workers who drink ethanol after exposure to trichloroethylene.

Risk Assessment: Past health assessment information on trichloroethylene is currently under review by EPA. EPA's past carcinogen assessment summary has been withdrawn and a new one is currently under development. According to EPA's preliminary risk assessment from ambient air exposures, public health risks are significant ( 4.1 cancer cases/year and maximum lifetime individual risks of 9.4E-5).

\subsection{AROMATIC HYDROCARBONS}

Aromatic hydrocarbons present special hazards as a class. The most toxic, benzene, causes damage to the blood-forming elements, and may cause aplastic anemia (bone-marrow destruction), or leukemia. 0ccupational studies have found severe brain abnormalities in children whose mothers had been exposed to the solvents toluene, xylene, and White Spirit during manufacture of rubber products.

\subsubsection{Benzene (2.2.1)}

Synonyms: benzol, coal naptha, cyclohexatriene, phene, phenyl hydride, polystream, and pyrobenzol

Benzene is classified as a human carcinogen. Numerous epidemiologic and case studies have reported an increased incidence or causal relationship between leukemia and exposure to benzene. Investigators have found significant increases in chromosomal aberrations of bone marrow cells and peripheral lymphocytes in workers exposed to benzene. Both ingestion and inhalation exposure of rodents to benzene have resulted in development of neoplasia (abnormal cell growth).

Benzene and its metabolites inhibit both nuclear and mitochondrial replication and transcription. Deoxyribonucleic acid (DNA) synthesis was inhibited in hemopoietic (blood-forming) cells from mice exposed to a single 
dose of 3,000 ppm benzene. Benzene metabolites rather than the parent compound are suspected of inducing bone marrow damage. Benzene metabolism, and therefore benzene toxicity, is altered by simultaneous exposure to some other solvents, e.g., xylene and toluene, which can increase the toxicity of the parent compound.

The half-life of benzene in air is 6 days.

Risk Assessment: Benzene is under review by the EPA for the determination of reference doses for chronic oral and inhalation exposures.

The inhalation slope factor for benzene is $2.9 \mathrm{E}-2 / \mathrm{mg} / \mathrm{kg} / \mathrm{day}$. The inhalation unit risk is $8.3 \mathrm{E}-6 / \mu \mathrm{g} / \mathrm{cu} . \mathrm{m}$. The extrapolation method used was the one-hit model using pooled data. The air concentrations at specified risk levels are:

Risk Leve $]$
$E-4(1$ in 10,000$)$
$E-5(1$ in 100,000$)$
$E-6(1$ in $1,000,000)$

Concentration

$\mathrm{lE}+\mathrm{l} / \mu \mathrm{g} / \mathrm{cu} \cdot \mathrm{m}$

$\mathrm{lE}+0 / \mu \mathrm{g} / \mathrm{cu} \cdot \mathrm{m}$

$\mathrm{IE}-1 / \mu \mathrm{g} / \mathrm{cu} \cdot \mathrm{m}$

\subsubsection{Ethyl Benzene (2.2.10)}

Synonyms: aethylbenzol, EP, ethylbonzol, and phenylethane

Chronic oral exposure to ethyl benzene can cause liver and kidney damage. Redness and inflammation may result from contact of skin with liquid. Prolonged exposure to vapors of ethyl benzene may result in functional disorders, increase in deep reflexes, irritation of upper respiratory tract, blood disorders, and liver complaints. Aspiration of even a small amount of ethyl benzene may cause severe injury, since its low viscosity and surface tension will cause it to spread over a large surface of lung tissue.

Ethyl benzene produces an irritant effect from chronic inhalation at $100 \mathrm{ppm} / 8$ hours. Ethyl benzene vapor has a transient irritant effect on human eyes at $200 \mathrm{ppm}$ in air. At 1,000 ppm on the first exposure, it is very irritating and causes tearing, but tolerance rapidly develops. At 2,000 ppm, 
eye irritation and tearing are immediate and severe; 5,000 ppm causes intolerable irritation of the eyes and nose.

Ethyl benzene is not classifiable as to human carcinogenicity due to lack of animal bioassays and human studies.

Risk Assessment: The reference dose for chronic oral exposure (RfDo) for ethyl benzene is $1 \mathrm{E}-1 \mathrm{mg} / \mathrm{kg} /$ day, with the critical effect being liver and kidney toxicity. The reference dose for chronic inhalation (RfDi) is not available at this time. The LOAEL of $408 \mathrm{mg} / \mathrm{kg} /$ day is associated with histopathologic (microscopic tissue structure) changes in the liver and kidneys.

\subsubsection{Propyl Benzene (2.2.15)}

Synonyms: isocumene, 1-phenylpropane and n-propyl benzene

The amount of toxicological information available for propyl benzene is very 1 imited. No specific studies involving the human toxicology of propyl benzene were found. Propyl benzene is considered mildly toxic by ingestion and inhalation.

\subsubsection{Styrene $(2.2 .17)$}

Synonyms: vinylbenzene, cinnamene, cinnamena 7 , cinnamol, ethenylbenzene, phenylethylene, phenethylene, phyenylethylene, and styrene monomer

Styrene is irritating to the eyes, respiratory and gastrointestinal tracts, and skin. The critical effect from oral exposure is on the red blood cells and liver. Repeated and prolonged contact of the liquid with the skin can cause defatting and dermatitis. The main pathological findings of exposure to styrene are edema (accumulation of fluid) of the brain and Tungs, and liver and kidney damage. Central nervous system depression may occur, peripheral neuropathies have been reported, and changes in psychoneurological functioning have been described with chronic exposure. "Styrene Sickness" is not uncommon in industry after exposure to vapors or mists. Characteristic signs and symptoms include headache, fatigue, weakness, depression and unsteadiness or a feeling of drunkenness, and abnormal EEGs. Reproductive 
system effects such as decreased frequency of births and increased frequency of spontaneous abortions in female workers have been reported.

Chronic or repeated inhalation of styrene can result in: 1) severe muscle weakness leading to limb paralysis and cardiac arhythmias (sensory function and tendon reflexes are not impaired); and 2) gastrointestinal complaints, including abdominal pain, nausea, and vomiting.

Styrene in concentrations of $100 \mathrm{ppm}$ in air causes mild irritation of eyes and throat in 20 minutes, but seems acceptable for working conditions. Concentrations of 400 and $500 \mathrm{ppm}$ cause irritation of eyes and nose, but can be tolerated. Exposure to styrene vapors above $800 \mathrm{ppm}$ is immediately irritating and can cause eye damage. Styrene air concentrations of 2,500 ppm are dangerous to 1 ife within 8 hours; concentrations of $10,000 \mathrm{ppm}$ are 1 ifethreatening within 20 to 30 minutes.

Styrene is questionabiy mutagenic and teratogenic. Styrene is among those substances being evaluated by the EPA for evidence of human carcinogenic potential. This does not imply that this chemical is necessarily a carcinogen. Studies of occupational exposure to styrene have found an increased rate of chromosomal aberrations in cultured lymphocytes for peripheral blood. An elevated incidence of hematopoietic (blood-forming elements) and lymphatic cancer has been reported for workers in the styrenebutadiene rubber industry.

Risk Assessment: The chronic oral exposure reference dose (RfDo) for styrene is $2 \mathrm{E}-\mathrm{l} \mathrm{mg} / \mathrm{kg} / \mathrm{day}$, with the critical effect on the red blood cells and the 1 iver. The NOAEL is $200 \mathrm{mg} / \mathrm{kg} /$ day and the LOAEL is $400 \mathrm{mg} / \mathrm{kg} / \mathrm{day}$. The risk assessment for the chronic inhalation reference dose is under review by an EPA work group.

\subsubsection{Toluene (2.2.19)}

Synonyms: methylbenzene, methacide, methylbonzol, phenylmethane, and toluol

Toluene is most likely a potential source of respiratory hazard. The only chronic toxicity study on toluene was conducted on rats. Occupational studies have found severe brain abnormalities in children whose mothers had been exposed to the solvents toluene, xylene, and white Spirit during the 
manufacture of rubber products. Toluene is not classified as to human carcinogenicity since there is no human data and the animal data is inadequate. Toluene did not produce positive results in the majority of genotoxic assays.

Risk Assessment: The chronic orat exposure reference dose (RfDo) for toluene is $3 E-1 \mathrm{mg} / \mathrm{kg} / \mathrm{day}$, with the critical effect on clinical chemistry and hematological parameters. The RfDo for toluene is under review by an EPA work group. The NOAEL for toluene is $300 \mathrm{ppm}$. There is no LOAEL listed for toluene.

\subsubsection{1,2,4-Trimethylbenzene (2.2.22)}

Synonyms: psi-cumene, pseudocumene, pseudocumo T, 1,2,5-trimethylbenzene, and trimethylbenzene

Trimethylbenzene is irritating to the skin, eyes, and mucous membranes. It can cause central nervous system depression and thrombocytopenia (decrease in blood platelets). Asthmatic bronchitis may be provoked by exposure to trimethylbenzene. Chemical pneumonitis (inflammation of the lungs) or pulmonary edema may deveiop, and headache, fatigue, nausea, and anxiety may be noted with exposures to trimethylbenzene.

One occupational exposure study reported symptoms of nervousness, tension, anxiety and asthmatic bronchitis in a "significant number" of people who worked for several years with "Fleet-X-DV-99," a solvent containing $30 \%$ 1,3,5-trimethylbenzene and 50\% 1,2,4-trimethylbenzene. Tendencies toward hyperchromic anemia and deviation in blood coagulation were also observed among these individuals. Concentrations for hydrocarbon vapor ranged from 10 to $60 \mathrm{ppm}$.

In cases of workers using paint thinner containing pseudocumene, there were symptoms of disturbance of blood coagulation and a tendency to blood clot formation with low levels of platelets and red blood cells. Bronchitis, headache, fatigue and drowsiness were experienced by $70 \%$ of workers exposed to high concentrations. 
Trimethylbenzenes are not classified as to human carcinogenicity because the EPA was unable to locate pertinent data regarding human oral or inhalation exposure in the available literature.

Risk Assessment: There are no adequate subchronic or chronic inhalation or oral data that define dose-specific adverse effects. Therefore, no reference doses (RfDs) are available for trimethylbenzene.

\subsubsection{Xylene (2.2.24)}

Synonyms: dimethylbenzene, 1,2-dimethylbenzene, 1,3-dimethylbenzene, 1,4-dimethylbenzene, $m-x y l e n e$, meta-xylene, $0-x y l e n e$, ortho-xylene, p-xylene, and para-xylene.

Xylene is a central nervous system depressant that produces lightheadedness, nausea, headache, and ataxia (loss of coordination) at low doses and confusion, respiratory depression, and coma at high doses. Above 200 ppm, xylene causes conjunctivitis, nasal irritation, and sore throats. It is a potent respiratory irritant at high concentrations.

Women are liable to suffer from menstrual disorders including excessive bleeding and nonmenstrual bleeding. It has been reported that female workers exposed to xylene in concentrations which periodically exceed the occupational exposure limits were also affected by pathological pregnancy conditions (toxicosis, danger of miscarriage, hemorrhage during childbirth) and infertility. Severe brain abnormalities occurred in children whose mothers had been exposed to the solvents toluene, xylene, and White Spirit during manufacture of rubber products.

Xylene is not classified as to human carcinogenicity and the animal data is considered inadequate.

Risk Assessment: The chronic oral exposure reference dose (RfDo) for $x y$ lene is $2 E+0 \mathrm{mg} / \mathrm{kg} /$ day, with the critical effects being hyperactivity and decreased body weight. The NOAEL for xylene is $250 \mathrm{mg} / \mathrm{kg} /$ day, and the FrankEffect Level (FEL) is $500 \mathrm{mg} / \mathrm{kg} /$ day. There are no quantitative risk estimates for either the oral or inhalation routes. 


\subsection{KETONES}

Ketones, commonly used in quick-drying finishes, have become more widespread with the increased popularity of vinyt resin finishes.

\subsubsection{Methy] Ethy] Ketone (2.2.12)}

Synonyms: 2-butanone, MEK, ethyl methyl ketone, and methylacetone

Methyl ethyl ketone is a strong irritant and is moderately toxic by ingestion and dermal exposure. Human systemic effects by inhalation include conjunctivitis, irritation and unspecified effects on the nose and respiratory system. It is considered a strong irritant, with human eye irritation occurring at $350 \mathrm{ppm}$. Methyl ethyl ketone affects the peripheral nervous system and central nervous system. Adequate chronic toxicity testing has not been performed on methyl ethyl ketone.

Methyl ethyl ketone is not classifiable as to human carcinogenicity because there is no human data available and the animal data is considered inadequate.

Risk Assessment: The RfDo for methy 1 ethy 1 ketone is $5 E-2 \mathrm{mg} / \mathrm{kg} /$ day with a critical effect statement that no adverse effects were observed. The NOAEL 1isted for methyl ethyl ketone is $235 \mathrm{ppm}$, and the LOAEL is 130.5 $\mathrm{mg} / \mathrm{kg} /$ day. No carcinogenic risk estimate is available for either the inhalation or oral routes of exposure.

\subsection{ALDEHYDES}

The aldehydes have strong unpleasant odors that can cause stress. Formaldehyde is the most well-known and best-studied VOC contaminant.

\subsubsection{Formaldehyde (2.2.11)}

Synonyms: formal in, formalin-40, forma 1 ith, formic aldehyde, formol, FYDE, BFV, FA, methanol, methylaldehyde, methylene glycol, methylene oxide, oxymethane, oxymethylene, Paraform, polyoxy methylene glycol, and Superlysoform

The main signs and symptoms of exposure are irritation of the eyes, nose and throat, tearing, cough, bronchospasm, pulmonary irritation, and dermatitis 
(which can be delayed). Solutions splashed in eyes have caused injuries ranging from severe, permanent corneal opacification (clouding) and loss of vision to minor discomfort. Severe pain, vomiting and diarrhea result from ingestion. After absorption, formaldehyde depresses the central nervous system and symptoms similar to alcohol intoxication result. It can also cause a reduction in body temperature. Effects in women include menstrual disorders and secondary sterility.

Medical conditions generally are aggravated by exposure to formaldehyde. In people sensitized to formaldehyde, late asthmatic reactions may be provoked by brief exposures of approximately $3 \mathrm{ppm}$. Data indicate an increased prevalence of chronic respiratory disease, chronic bronchitis or asthma in children 6 to 15 years of age living in houses with formaldehyde concentrations between 60 and 140 parts per billion (ppb).

Below $1 \mathrm{ppm}$, the odor of formaldehyde is perceptible to most people. At 2 to $3 \mathrm{ppm}$, mild tingling of the eyes occurs. At 4 to $5 \mathrm{ppm}$, increased discomfort with mild tearing occurs. At $10 \mathrm{ppm}$, profuse tearing occurs and can be withstood only for a few minutes. At 10 to $20 \mathrm{ppm}$, breathing difficulties, cough, and severe burning of nose and throat occur. At 50 to $100 \mathrm{ppm}$, very serious injury is likely. The following shows the health effects at different concentrations:

\section{Health Effects Reported}

No effects

Eye irritation

Nose and mucous membrane irritation

Neurophysiological effects

Upper airway irritation

Lower airway irritation

Dermatitis

Nausea and vomiting
Avg. Formaldehyde

Concentration (ppm)
$0.02-0.26$
$0.02-0.38$
$0.02-0.38$
$0.02-0.38$
$0.03-0.38$
$0.06-0.11$
$0.04-0.14$
$0.03-0.13$ 
Although the human carcinogenicity data are limited, formaldehyde is classified as a probable human carcinogen based on evidence from animal studies. Studies of workers exposed to formaldehyde (1argely through resin formation) have observed significant excesses in lung and nasopharyngeal cancer deaths. One case study showed a significant association between nasopharyngeal cancer and having lived 10 or more years in a mobile home. People for whom this association was drawn had lived in mobile homes built in the 1950 s to 1970 s, a period of increasing formaldehyde-resin usage, but no measurements were directly available or used.

other studies indicate a possibility that observed leukemia and neoplasms (abnormal growths) of the brain and colon may be associated with formaldehyde exposure. Although the common exposure in all of these studies was formaldehyde, the epidemiologic evidence is categorized as "limited," primarily owing to possible exposures to other agents. Such exposures could have contributed to the findings of excess cancers.

Risk Assessment: A risk assessment for noncarcinogenic effects of formaldehyde exposure is under review by an EPA work group.

The inhalation slope factor for formaldehyde is $4.5 \mathrm{E}-2 / \mathrm{mg} / \mathrm{kg} / \mathrm{day}$. The inhalation unit risk is $1.3 \mathrm{E}-5 / \mu \mathrm{g} / \mathrm{cu} . \mathrm{m}$. The extrapolation method used was the linearized multistage procedure using additional risk. The air concentrations at specified risk levels are:

\begin{tabular}{lll} 
Risk Leve 1 & & Concentration \\
\hline $\mathrm{E}-4(1$ in 10,000$)$ & & $8 / \mu \mathrm{g} / \mathrm{cu} . \mathrm{m}$ \\
$\mathrm{E}-5(1$ in 100,000$)$ & & $8 \mathrm{E}-1 / \mu \mathrm{g} / \mathrm{cu} . \mathrm{m}$ \\
$\mathrm{E}-6$ (1 in $1,000,000)$ & & $8 \mathrm{E}-2 / \mu \mathrm{g} / \mathrm{cu} . \mathrm{m}$
\end{tabular}




\subsection{RADON/RADON PROGENY $(2.2 .16)$}

Radon is a decay product of uranium and it, in turn, decays to form radioactive progeny that may attach to dust particles or remain unattached. If these progeny are inhaled, they can be drawn into the lungs, where they emit alpha energy and may cause lung cancer. The EPA has withdrawn its carcinogen assessment for radon and its progeny since a new carcinogen summary is in preparation by the CRAVE Work Group. Thus, the assessment information presented may be subject to change as a result of the new carcinogen summary.

The major health effects in experimental studies that simulate exposures in the mine environment are pulmonary emphysema, pulmonary fibrosis (scarring of the lung tissue), pneumoconiosis (lung disease from mineral dust), lung cancer, and life-span shortening. In animals exposed to radon progeny, lesions observed in organs other than the lung are considered spontaneous or only indirectly related to exposure effects. In human organs other than the lung, lesions are either not prominent or cannot unequivocally be associated with radon-progeny exposures alone.

In general, pulmonary fibrosis (lung scarring), emphysema, and lifespan shortening are not produced to any significant extent until exposures exceed about 5,000 working level months (WLM). However, lung cancer is produced in studies with rats down to levels of $20 \mathrm{WLM}$, which are typical average human lifetime environmental exposure levels. Respiratory carcinoma, therefore, is the most prominent health effect associated with radon progeny. The risk of radon-progeny-related lung cancer could ultimately be dependent on sex, life span (which leads to overall higher lifetime lung-cancer risk), and smoking history. Lung cancer rarely appears before age 40, regardless of age at exposure, and never before a minimum latent interval of 5 to 10 years following exposure.

The data are not yet fully consistent or developed, but most indicate that tobacco smoke acts mainly as a cancer promoter. The U.S. uranium-miner data indicate that smokers have a shorter induction-latent period and a higher incidence of lung cancer than nonsmokers. 
Risk Assessment: In general, except for persons over age 60 , the lifetime risk appears to be between 1 and 2 per 10,000 per WLM. Although this is a small risk, the large number of persons exposed in the United States yields a significant number of lung cancers. 


\subsection{ADDITIONAL CAULK-ASSOCIATED COMPOUNDS}

Three other compounds are additional contaminants found in caulking material. These contaminants were not specifically reported as being found in the commercial building measurement studies reviewed, but are included here for completeness. If these contaminants are detected in building caulking material, they are very likely to be released to the indoor air of a commercial building.

\subsection{CARBITOL $(2.2 .25 .1)$}

Synonyms: carbitol cellosolve with carbitol solvent, diethylene glycol ethyl ether, dioxitol, diglycol monoethyl ether, ethoxy diglycol, 2-(2-ethoxyethoxy)ethanol, ethylcarbitol, ethyldiethyleneglycol, Poly-Solv, and Solvsol

The amount of information regarding the toxicological effects of carbitol is very limited; no studies of human toxicology were found. Carbitol is a skin and eye irritant. Experimental reproductive effects are associated with it. Animal studies have shown that carbitol is moderately toxic by ingestion and mildly toxic by skin contact.

\subsection{ETHYLENE GLYCDL $(2.2 .25 .2)$}

Synonyms: 1,2-dihydroxyethane, 1,2-ethanediol, ethylene alcohol, ethylene dihydrate, glycol, glycol alcohol, MEG, monoethylene glycol, Norkool, and Tescol.

The amount of toxicological information available for ethylene glycol is limited. Kidney toxicity is listed as the critical effect of oral exposure. Ethylene glycol is in the same range of toxicity as methyl ethyl ketone, propylenedichloride, and tetrachloroethane, but its hazards are believed to be less because its vapor pressure is substantially lower.

Ethylene glycol has not been evaluated by the EPA for evidence of human carcinogenic potential. 
Risk Assessment: The chronic oral exposure reference dose (RfDo) for ethylene glycol is $2 E+0 \mathrm{mg} / \mathrm{kg} / \mathrm{day}$, with kidney toxicity listed as the critical effect. There is no chronic inhalation reference dose (RfDi) available at this time. The NOAEL is $200 \mathrm{mg} / \mathrm{kg} /$ day, and the LOAEL is $1,000 \mathrm{mg} / \mathrm{kg} / \mathrm{day}$.

\subsection{OCTENE $(2.2 .25 .3)$}

Synonyms: None.

No toxicological information is available on octene at this time. 


\subsection{COMBUSTION PRODUCTS}

Pollutant emissions from indoor combustion vary considerably as a function of the type of fuel, the type and condition of the appliance, and the conditions under which combustion takes place. Tobacco smoking, gas-fired appliances, wood stoves, fireplaces, and kerosene heaters are some of the major sources of combustion by-products that can contaminate indoor air. Emissions from vehicles in attached or underground garages or from outside traffic, with emissions being brought in through the ventilation systems, also contribute to indoor air contamination.

The major combustion products are carbon dioxide $\left(\mathrm{CO}_{2}\right)$, water vapor, carbon monoxide $(\mathrm{CO})$, nitrogen dioxide, sulfur dioxide, aldehydes and other organic compounds, and particulate matter. Among the aldehydes and other organic compounds associated with combustion products, formaldehyde and benzo[a]pyrene are the sources of greatest concern. Formaldehyde was discussed in Section 3. Benzo[a]pyrene, discussed in this section, is a ubiquitous polyaromatic hydrocarbon (PAH) produced during combustion of coal, wood, tobacco, diesel fuel, and tar, and in some commercial processes. It has been extensively studied and shown to be a potent carcinogen in experimental animals and in human tissues. Wood combustion and tobacco smoke are the main sources of the normally fairly low levels of benzo[a]pyrene found in the indoor environment.

Metabolic activity is responsible for most of the $\mathrm{CO}_{2}$ concentration in the indoor environment, al though gas and kerosene heaters also emit appreciable quantities of $\mathrm{CO}_{2}$. Carbon monoxide is a product of incomplete combustion. Oxides of nitrogen are formed when combustion takes place at high temperatures. Sulfur oxides are combustion products of sources burning sulfurcontaining fuels (e.g., kerosene and coal). In general, sulfur oxides are usually more of a concern with outdoor ambient air quality. 


\subsection{BENZO [a]PYRENE $(2.3 .1 .1)$}

Synonyms: 3,4-benzopyrene, 6,7-benzopyrene, 3,4-benzo[a]pyrene, and 3,4benzopyrene

As a polyaromatic hydrodcarbon (PAH), benzo[a]pyrene is not chemically reactive with cellular components of living organisms. Rather, it is a procarcinogen that is metabolized by living cells into carcinogenic derivatives capable of reacting directly with the macromolecules in animals and humans. Benzo[a]pyrene has been widely used as a reference compound for estimating human health effects for emissions and effluent suspected of posing a carcinogenic risk to human populations. It is among the best-studied agents producing genetic toxicological effects.

Benzo[a]pyrene is classified as a probable human carcinogen. Human data specifically linking benzo[a]pyrene to a carcinogenic effect are lacking. Lung cancer has been shown to be induced in humans by various mixtures of polycyclic aromatic hydrocarbons known to contain benzo[a]pyrene, including cigarette smoke, roofing tar, and coke-oven emissions. It is not possible, however, to conclude from this information that benzo[a]pyrene is the responsible agent, because it is not normally encountered in the environment (either ambient or indoor) as a pure compound. Rather, it occurs with many other organics in what are commonly referred to as complex mixtures. For example, benzo[a]pyrene is encountered in cigarette smoke along with about 5,000 other compounds and in coal-derived products with as many as 2,500 other compounds. However, multiple animal studies demonstrate benzo[a]pyrene to be carcinogenic following administration by oral, intratracheal, inhalation, and dermal routes.

The carcinogenicity observed in association with benzo[a]pyrene is believed to come from its metabolic derivatives (which range from noncarcinogenic to extremely carcinogenic) rather than from the compound itself. Differences in the reactions of different human organs to benzo[a]pyrene have been demonstrated. For example, the urinary bladder appears to be most sensitive, followed in decreasing order by the skin, bronchus, esophagus, and 
colon, and there are significant variations in the susceptibility of tissues taken from different individuals, some of which appear to be associated with genetic differences.

Risk Assessment: There is no dose response information on the experimental or occupational exposure of humans to benzo[a]pyrene. No quantitative estimates of carcinogenic risk from oral or inhalation exposure are available at this time.

\subsection{CARBON MONOXIDE $(2.3 .3)$}

Synonyms: carbonic oxide and carbon oxide

Carbon monoxide (CO) in the blood forms carboxyhemoglobin, a form of the hemoglobin in which the oxygen is displaced by carboxyl groups. This causes hypoxia (oxygen deficiency) by reducing the ability of blood to transport oxygen throughout the body and, at sufficiently high concentrations, can cause asphyxiation. Relatively low atmospheric concentrations of $C 0$ can result in significant oxygen deprivation. The central nervous system (CNS), the cardiovascular system, and the liver are tissues most sensitive to co-induced hypoxia. Symptoms of CNS hypoxia include loss of alertness; impaired perception and judgment; loss of coordination; reduced performance, vigilance, and concentration; drowsiness; confusion; and, at sufficiently high concentrations and exposure lengths, coma and death.

Cardiovascular hypoxia causes a decrease in exercise time to produce angina pectoris (chest and arm pain), increased incidence of myocardosis (degeneration of heart muscle), and increased probability of heart failure in susceptible patients.

Populations at special risk include fetuses; patients with certain health problems, such as cardiovascular or chronic respiratory diseases (bronchitis, emphysema, or asthma); individuals under the influence of drugs or alcohol; the elderly; and persons not adapted to high altitude who are exposed to carbon monoxide at high altitudes. A combination of any two or more risk factors increases the risk accordingly. 
Infants born to women who have survived acute exposure to a high concentration of carbon monoxide while pregnant often display neurological sequelae, and there may be gross damage to the brain. Persistent low levels of carboxyhemoglobin in the fetuses of women who smoke may also reduce infants' mental abilities.

\subsection{CARBON DIOXIDE $(2.3 .2)$}

Synonyms: carbonic acid gas and carbonic anhydride

It is recognized that repeated daity inhalation exposure at 0.5 to $1.5 \%$ carbon dioxide at 1 atmosphere pressure is we11 tolerated by normal individuals. Two percent carbon dioxide in inhaled air increases pulmonary ventilation $50 \%$. Dizziness, headache, confusion, and difficult breathing occur at 5\% concentration carbon dioxide. Eight to ten percent causes severe headache, sweating, dimness of vision, and tremor. Consciousness is lost after 5 to 10 minutes.

\subsection{ENVIRONMENTAL TOBACCO SMOKE $(2.3 .4)$}

The harmful effects of smoking on the smoker are well known and documented. However, health effects of chronic involuntary exposure of nonsmokers to environmental tobacco smoke (ETS) at concentrations that generally are well below recommended threshold limit values (TLV) for the individual chemicals are still controversial. Acute effects on susceptible individuals, mainly headaches and temporary irritation of the eyes and mucous membranes of the upper respiratory tract, are generally recognized. By contrast, there is still heated debate over the results of epidemiological studies linking involuntary exposure of ETS to 1) an increased incidence of cancer in nonsmoking spouses; 2) morbidity (especially respiratory diseases) in infants and children of smoking parents (especially smoking mothers); and 3) aggravation of symptoms in patients with cardiovascular and chronic obstructive lung diseases (COLO). Even within the biomedical community, opinions vary widely.

In view of the difficulties of 1) making meaningful concentration measurements; 2) developing standards for normalizing exposures occurring under widely varying conditions; 3 ) conducting "perfect" epidemiological 
studies; 4) developing a consensus regarding the interpretation of results of such studies; and 5) resotving the existing disagreements and controversy in the biomedical community regarding these issues, no meaningful risk assessments for ETS exposures and quantifications of health effects can be made at this time.

For the past 18 months, EPA has been reviewing the effects of ETS. In the past, EPA has used estimates by private researchers on the damage caused by ETS. These estimates have ranged from 12 to 5,200 additional lung cancer deaths annually in the United States and as many as 46,000 deaths overall if illnesses such as heart disease and respiratory ailments are included. The EPA findings are currently in draft form and still must be reviewed by the agency's Scientific Advisory Board.

\subsection{NITROGEN OXIDES $(2.3 .5)$}

Oxides of nitrogen technically include nitric oxide (NO), nitrogen dioxide $\left(\mathrm{NO}_{2}\right)$, nitrous oxide $\left(\mathrm{N}_{2} \mathrm{O}\right)$, nitrogen trioxide (00NO), dinitrogen trioxide $\left(\mathrm{N}_{2} \mathrm{O}_{3}\right)$, dinitrogen tetraoxide $\left(\mathrm{N}_{2} \mathrm{O}_{4}\right)$, and dinitrogen pentoxide $\left(\mathrm{N}_{2} \mathrm{O}_{5}\right)$. All of these compounds, as well as their secondary reaction products (e.g., nitrate aerosols), can affect human health. However, only $\mathrm{NO}$ and $\mathrm{NO}_{2}$ are of practical importance as indoor air pollutants. Both compounds are produced from atmospheric nitrogen and oxygen during the combustion process. The biological effects of $\mathrm{NO}_{2}$ have been extensively studied during the past 30 years.

Nitric oxide is relatively nontoxic at normally encountered concentrations, but persists longer indoors than outside and has a longer indoor halflife than $\mathrm{NO}_{2}$. Therefore, it cannot be ignored as an indoor air pollutant. Nitrogen dioxide is a respiratory irritant, affecting the respiratory system not unlike ozone $\left(\mathrm{O}_{3}\right)$, but to a lesser degree. Both $\mathrm{NO}$ and $\mathrm{NO}_{2}$ reduce the oxygen-carrying capacity of the blood, and oxides of nitrogen can cause acute and chronic changes in the small airways and lungs. Oxides of nitrogen form potentially carcinogenic nitrosamines in the respiratory tract and in the acid milieu of the stomach, which might also contribute to liver dysfunction. 
Children and persons with asthma, chronic bronchitis, and emphysema appear to be the most sensitive population groups. Persons with hay fever or liver, blood, or hormonal disorders can also be affected by low levels of $\mathrm{NO}_{2}$. Studies suggest that $\mathrm{NO}_{2}$ can cause adverse health affects in sensitive population groups exposed to levels at or near existing ambient levels.

Risk Assessment: The chronic oral exposure reference dose (RfDo) for $\mathrm{NO}_{2}$ is $1 \mathrm{E}+\mathrm{O} \mathrm{mg} / \mathrm{kg} /$ day, with methemoglobinemia (reduction of the oxygencarrying capacity of the lung) as the critical effect. The NOAEL is $10 \mathrm{ppm}$ of drinking water. The LOAEL is 11 to $20 \mathrm{ppm}$. Currently, there is no chronic inhalation exposure reference dose (RfDi) for $\mathrm{NO}_{2}$. A risk assessment for $\mathrm{NO}_{2}$ is under review by an EPA work group. 


\subsection{EIBERS (2.4)}

Mineral fibers include both natural fibers (predominantly asbestos) and synthetic fibers (predominantly fiber glass and mineral [rock] w001). Asbestos is a generic term referring to hydrated magnesium (with the exception of crocidolite) silicate fibers, which are characterized by flexibility, strength, and resistance to fire and chemicals. These desirable characteristics have resulted in numerous industrial applications of asbestos (predominantly chrysotile). These applications include thermal and acoustic insulation in buildings and ships; additives to construction and building materials; filters and gaskets; and textiles (e.g., fire-resistant clothing). Table 7.1 lists several types of fibers potentially encountered in commercial buitdings.

\subsection{ASBESTOS (2.4.1)}

Asbestos is the name applied to a group of six different minerals that occur naturally in the environment. The most common mineral type is white, but others may be blue, gray, or brown. These minerals are made up of long, thin fibers that are somewhat similar to fiber glass. Asbestos fibers are very strong and are resistant to heat and chemicals. Because the fibers are so resistant to chemicals, they are also very stable in the environment; they do not evaporate into the air or dissolve in water, and they are not broken down over time.

The current EPA carcinogen assessment summary for asbestos may change in the near future pending the outcome of further review now being conducted by the CRAVE Work Group. The current EPA classification for asbestos is "A; human carcinogen." The basis for the classification is a large number of studies that conclusively demonstrate increased mortality and incidence of lung cancer, mesotheliomas, and gastrointestinal cancer among exposed workers. These results have been corroborated by animal studies. Animal evidence for carcinogenicity via ingestion is 1 imited, and epidemiological data are inadequate. 
IABLE 7.1. Types of Fibers Potentially Encountered in Commercial Buildings

\author{
Naturally Occurring Fibers
}

Asbestos

Serpent ine

Chrysotile $-\mathrm{Mg}_{3}\left(\mathrm{Si}_{2} \mathrm{O}_{3}\right)(\mathrm{OH})_{4}$

Amphiboles

Actinolite $-\mathrm{Ca}_{2}(\mathrm{Mg}, \mathrm{Fe})_{5}\left(\mathrm{Si}_{8} \mathrm{O}_{22}\right)(\mathrm{OH})_{2}$

Amosite - $(\mathrm{Fe}, \mathrm{Mg})_{7}\left(\mathrm{Si}_{8} \mathrm{O}_{22}\right)(\mathrm{OH})_{2}$

Anthophyllite - $(\mathrm{Mg}, \mathrm{Fe})_{7}\left(\mathrm{Si}_{8} \mathrm{O}_{22}\right)(\mathrm{OH})_{2}$

Crocidolite - $\mathrm{Na}_{2} \mathrm{FeII}_{3} \mathrm{FeIII} 2\left(\mathrm{Si}_{8} \mathrm{O}_{22}\right)(\mathrm{OH})_{2}$

Tremolite $-\mathrm{Ca}_{2} \mathrm{Mg}_{5}\left(\mathrm{Si}_{8} \mathrm{O}_{22}\right)(\mathrm{OH})_{2}$

Nonasbestos Fibers

Attapulgite (palygorskite)

Sepiolite (including meerschaum)

Noncommercial natural mineral fibers

Synthetic Fibers

Vitreous Fibers

Fibrous glass

Mineral wool (rock wool, slag wool)

Ceramic fibers

Other Synthetic Fibers

Carbon fibers

Miscellaneous others

Risk Assessment: The inhalation slope factor for asbestos is $2.3 \mathrm{E}-1 /$ fibers $/ \mathrm{mL}$. The inhalation unit risk estimate for asbestos is 2.3E-1/fibers $/ \mathrm{mL}$. The extrapolation method used was the additive risk of lung cancer and mesothelioma, using the relative risk model for lung cancer and the absolute risk model for mesothelioma. The air concentrations at specified risk levels are: 


\begin{tabular}{ll} 
Risk Level & Concentration \\
\hline$E-4(1$ in 10,000$)$ & $4 E-4$ fibers $/ \mathrm{mL}$ \\
$E-5(1$ in 100,000$)$ & $4 E-5$ fibers $/ m L$ \\
$E-6(1$ in $1,000,000)$ & $4 E-6$ fibers $/ m L$
\end{tabular}

\subsection{SYNTHETIC FIBERS (2.4.2)}

Lack of convincing evidence and reliable information at present does not permit a meaningful risk assessment of exposure to synthetic fibers in enclosed spaces. Some, but not all, animal studies show that synthetic fibers can result in pulmonary disease. One occupational study noted a significant excess of nonmalignant respiratory diseases in workers exposed to glass fibers. However, the evidence is not considered conclusive because of the number of studies showing no effects in humans and animals.

No epidemiological evidence exists at this time to link any of the synthetic fiber substitutes for asbestos to lung cancer. However, the use of these materials is relatively new. If they are indeed carcinogenic, and if cancers resulting from such exposure had latency periods similar to those induced by asbestos, these cancers would not manifest themselves epidemiologically until after the turn of the century. 


\subsection{BIOGENIC PARTICLES (2.5)}

Biogenic indoor air pollutants include viruses, bacteria, fungi, algae, pollens and other plant-derived materials, protozoa, helminths, arthropods (particularly mites) and insects, their excretions and body fragments, bird feathers, dander of dogs and cats, and human epidermal scales. The dust in commercial buildings contains varying proportions of these materials. Some of these biogenic air pollutants originate outdoors and invade the buildings from there (e.g., pollens). Others originally migrated from outdoors, but subsequently established themselves in the indoor environment (e.g., bacteria, fungi, arthropods, insects); still others of them are generated indoors (e.g., human and pet danders).

Unlike most of the chemical air pollutants, which may be toxic, carcinogenic, or both, the health effects of biogenic air contaminants usually are infectious diseases and allergic reactions. The list of infectious diseases linked to biogenic air pollutants includes "colds," influenza, measles, chicken pox, smallpox, tuberculosis, Legionnaires' Disease, pneumonia, and several fungal diseases. They can also cause hay fever, asthma, hypersensitivity pneumonitis (inflammation of the lungs), and extrinsic allergic bronchioloalveolitis. Tissue changes caused by acute allergic reactions are reversible. However, if exposure to the offending allergen turns chronic, reversibility diminishes and eventually irreversible lesions will develop, often in the form of pulmonary fibrosis (Tung scarring).

Little is known about indoor air concentrations of biogenic particles in commercial buildings and the effect of environmental changes on those concentrations. Systematic, standardized, and coordinated measurements would be required to provide an essential information base for developing guidelines for exposures to biogenic indoor air pollutants. The problem is complicated by the fact that, because of the great diversity in physiochemical and biological characteristics of biogenic particles, no single sampling or sample processing technique can cover the entire spectrum of biogenic particles. Therefore, no meaningful risk assessment of exposure to biogenic indoor air pollutants in commercial buildings can be made at this time. 
4

. 


\subsection{POLYCHLORINATED BIPHENYLS (3.1)}

Polychlorinated biphenyls (PCBs) belong to a broad family of organic chemicals called chlorinated hydrocarbons. PCBs range in consistency from heavy oily liquids to waxy solids. Prior to 1979, PCBs were widely used as coolants in electrical equipment, such as transformers, capacitors, and switches, because the compounds do not easily burn, conduct electricity, or react with other chemicals. When released into the environment, PCBs do not easily decompose. The compounds are relatively insoluble in water and have a high solubility in fats.

The liver and skin are the primary targets of $\mathrm{PCB}$ toxicity. In humans exposed to PCBs, reported adverse effects include chloracne (a long-lasting, disfiguring skin disease), impairment of liver function, a variety of neurobehavioral and affective symptoms, menstrual disorders, minor birth abnormalities, and probably an increased incidence of cancer. Animals experimentally exposed to PCBs have shown most of the same symptoms, as well as impaired reproduction, pathological changes in the liver, stomach, skin, and other organs, and suppression of immunological functions. PCBs are carcinogenic in rats and mice and, in certain circumstances, enhance the effects of other carcinogens. Reproductive and neurobiological effects of PCBs have been reported in rhesus monkeys at the lowest dose level tested.

The weight-of-evidence classification for PCBs is "B2; probable human carcinogen." The basis is liver cancers in rodents as well as inadequate, yet suggestive, evidence of excess risk of liver cancer in humans by ingestion, inhalation, and dermal contact. Although there are many studies, the human data are inadequate due to confounding exposures or lack of exposure quantification.

Risk Assessment: The oral slope factor for PCBs is $7.7 / \mathrm{mg} / \mathrm{kg} / \mathrm{day}$. The drinking water unit risk is $2.2 \mathrm{E}-4 / \mu \mathrm{g} / \mathrm{L}$. The extrapolation method used was the linear multistage procedure with extra risk. Drinking water concentrations at specified risks levels are: 
Risk Level

$E-4$ (1 in 10,000$)$

$\mathrm{E}-5$ ( 1 in 100,000$)$

$\mathrm{E}-6(1$ in $1,000,000)$
Concentration

$5 \mathrm{E}-1 \mu \mathrm{g} / \mathrm{L}$

$5 \mathrm{E}-2 \mu \mathrm{g} / \mathrm{L}$

$5 \mathrm{E}-3 \mu \mathrm{g} / \mathrm{L}$ 


\subsection{CHLOROFLUOROCARBONS (4.0)}

Halocarbons are a family of chemically stable compounds derived from common hydrocarbons such as methane, ethane, and propane, and include chlorofluorocarbons (CFCs), hydrogenated chlororfluorocarbons (HCFCs), and hydrogenated fluorocarbons (HFCs). In CFCs, the most common halocarbons, all of the hydrogen atoms surrounding the carbon atoms in the original hydrocarbons are replaced by either fluorine or chlorine, two of the so-called "halogen" elements. CFCs are used in commercial buildings as propellants and refrigerants and are the foaming agents used in low-density insulating materials for buildings and appliances. CFCS have life expectancies of approximately 100 years.

CFCs have the potential to impact human health in two ways: the toxicological effects of the contaminants themselves, and the health impact associated with their role in reducing the stratospheric ozone layer. In this report, three of the more common CFCs were selected to examine for direct health effects. They are 1,1,2-trichloro-1,2,2-trifluoroethane (CFC-113 or freon-113); trichlorofluoromethane (freon-11); and dichlorodifluoromethane (freon F-12). The human health impacts of the reduction of the stratospheric ozone layer are part of a very involved and ongoing investigative process. Since CFCs are only one of many potential contributing factors to ozone depletion, only a very general discussion of the potential health effects is provided.

\subsection{DIRECT EFFECT OF CFCS (4.1)}

The EPA IRIS database maintains information on three CFCS of concern: 1,1,2-trichloro-1,2,2-trifluoroethane (CFC-113 or freon-113); trichlorofluoromethane (freon-11); and dichlorodifluoromethane (freon F-12).

\subsubsection{1,1,2-Trichloro-1,2,2-Trifluoroethane (freon-113) (4.1.1)}

Several animal inhalation studies reported negative results in dogs, rabbits, and rats chronically exposed to very high concentrations of trichlorotrifluoroethane. No apparent adverse effects have been reported in humans occupationally exposed to trichlorotrifluoroethane at either 
$500 \mathrm{mg} / \mathrm{cu} . \mathrm{m}$ levels for 11 years or $5,358 \mathrm{mg} / \mathrm{cu} . \mathrm{m}$ for 2.77 years. S1 ight impairment of psychomotor performance was reported in male volunteers exposed to trichlorotrifluoroethane concentrations of $19,161 \mathrm{mg} / \mathrm{cu} . \mathrm{m}$ for 2.75 hours.

Trichlorotrifluoroethane has not been evaluated by the EPA for evidence of human carcinogenic potential.

Risk Assessment: The chronic oral exposure reference dose (RfDo) for trichlorotrifluoroethane is $3 E+1 \mathrm{mg} / \mathrm{kg} / \mathrm{day}$, with the critical effect being psychomotor impairment. The NOAEL is $5,358 \mathrm{mg} / \mathrm{cu} . \mathrm{m}$ (can be converted to $273 \mathrm{mg} / \mathrm{kg} / \mathrm{day}$ ). The RfDo may change in the near future pending the outcome of a review currently being conducted by an EPA work group. There is no chronic inhalation reference dose ( $R F D i$ ) available at this time.

\subsubsection{Irichlorofluoromethane (freon-11) (4.1.2)}

Animal studies of exposure by inhalation to trichlorofluoromethane reported no signs of toxicity with subchronic or short-term exposures. One study did find a statisticalty significant positive association between increased ingestion exposure and accelerated mortality in rats, as well as elevated incidences of pleuritis and pericarditis (inflammation of the lung and heart membranes).

Trichlorofluoromethane has not been evaluated by the EPA for evidence of human carcinogenic potential.

Risk Assessment: The chronic oral exposure reference dose (RfDo) for trichlorofluoromethane is $3 \mathrm{E}-\mathrm{l} \mathrm{mg} / \mathrm{kg} /$ day, with survival and histopathology (changes in microscopic tissue structure) as the critical effects. There is no chronic inhalation reference dose ( $R f D i$ ) available at this time. No NOAEL was established. The LOAEL is $488 \mathrm{mg} / \mathrm{kg} /$ day (can be converted to $349 \mathrm{mg} / \mathrm{kg}$ / day).

\subsubsection{Dichlorodifluoromethane (freon $F-12$ ) (4.1.3)}

A 2-year study of rats and dogs exposed to dichlorodifluoromethane in their diet found no adverse effects attributable to this compound except for decreased weight gain in rats. 
Risk Assessment: The chronic oral exposure reference dose (RfDo) for dichlorodifluoromethane is $2 \mathrm{E}-1 \mathrm{mg} / \mathrm{kg} /$ day, with reduced body weight being the critical effect. There is no chronic inhalation reference dose (RfDi) available at this time. The NOEL is $300 \mathrm{ppm}$ (can be converted to $15 \mathrm{mg} / \mathrm{kg} / \mathrm{day}$ ). The LOAEL is 3,000 ppm (can be converted to $150 \mathrm{mg} / \mathrm{kg} / \mathrm{day}$ ).

\subsection{STRATOSPHERIC OZONE LAYER REDUCTION HEALTH EFFECTS (4.2)}

There is considerable research taking place on, and considerable controversy over, the reduction of the stratospheric ozone layer which filters ultraviolet radiation from the sun. Any significant change in the attenuation of ultraviolet radiation by the ozone layer potentially has a very direct effect on human health. The amount of sunlight reaching humans directly affects the amount of vitamin $D$ produced in the skin. For example, a substantial reduction in ultraviolet radiation would lead to vitamin $D$ deficiencies. On the other hand, if the ultraviolet radiation increased considerably, severe skin problems would result.

The EPA has predicted that every $1 \%$ decrease in ozone will result in a $1 \%$ to $2 \%$ increase in melanoma skin cancer incidence. According to the agency, there could be $40 \mathrm{milli}$ ion excess cases of skin cancer and 800,000 excess cancer deaths through the year 2075 due to a thinning ozone layer. Other expected effects of ozone depletion include increased incidence of cataracts, increased production of tropospherical ozone (smog), crop damage, and increased degradation of manmade materials such as polymers.

CFCs are compounds containing fluorine, chlorine, carbon, and sometimes hydrogen, all of which can cause stratospheric ozone depletion. However, the CFCs considered in the previous section are only one of several contributors to the problem. For example, proposed supersonic jet flights in the upper atmosphere have been a major concern. Nitric oxides released from these planes will react with ozone to cause a reduction in the average ozone concentration at those altitudes. A second threat posed by the release of CFCs into the atmosphere relates to global warming. CFCs contribute indirectly to global warming through ozone depletion. They also contribute directly to atmospheric warming because CFCs, like carbon dioxide, are greenhouse gases. 
The global warming potential (GWP) is a term designating the relative potential of various greenhouse gases to absorb long-wave radiation and, therefore, produce additional heat. The GWP of CFCs are as much as 10,000 times as great as that of carbon dioxide. 


\subsection{GLOSSARY}

\section{Biomedical Terms}

Anemia:

A condition marked by significant decreases in hemoglobin concentration and in the number of circulating red blood cells.

Angina pectoris: Constricting chest pain which may be accompanied by pain radiating down the arms, up into the jaw, or to other sites.

Anoxic stress: Oxygen starvation.

Ataxia:

Loss of coordination.

Bronchioloalveolitis: Inflammation of the bronchi and alveoli.

Bronchospasm:

Temporary narrowing of the bronchi due to violent, involuntary contraction of the smooth muscle of the bronchi.

Conjunctivitis:

Inflammation of the membrane covering the white of the eye and lining the inside of the eyelids.

Cyanosis:

A bluish color in the skin and mucous membranes due to deficient levels of oxygen in the blood.

Dyspnea:

Difficult or labored breathing.

Edema:

Accumulation of fluid which causes swelling.

Emphysema :

Swelling of the air sacs or the tissue connecting them in the lungs, accompanied by atrophy of the tissues and impaired breathing.

Erythema:

Skin redness.

Fetotoxic:

Toxic to the fetus.

Genotoxic:

Toxic to the genetic material within a person's cells, i.e., in the genes formed from the substance deoxyribonucleic acid (DNA), which make up the chromosomes in the cells.

Hematopoietic:

Hepatic:
Having to do with the blood-forming elements.

Having to do with the liver. 
Hemoptysis:

Hydranencephaly:

Hyperchromic anemia:

Hypoxia:

Lymphocytes:

Mesothelioma:

Methemoglobinemia:

Mutagenic:

Nasopharyngeal:

Neoplasm:

Neurological sequelae: A nervous system condition that results from or

Pheochromocytoma:

Pleuritis:

Pneumoconiosis:

Pulmonary edema:

Renal:

Rhinitis: follows a disease, disorder or injury, i.e., complications of a neurologic injury.

Discharge of blood from the larynx, trachea, bronchi or Tungs; coughing up blood.

A congenital anomaly in which the brain is not fully developed.

Any of several blood disorders in which red blood cells show an increase in hemoglobin and a reduction in number.

Oxygen deficiency caused by a reduction of the blood's oxygen carrying capacity.

The principal cell type of the lymphs which composes $20 \%$ to $30 \%$ of white blood cells.

A tumor of the pleura, the linings of the lungs and chest cavity.

The presence of methemoglobin (oxidized hemoglobin) in the blood, which reduces the oxygen carrying capacity of the blood.

Causing cell mutation, chromosome alterations, bacterial mutations, and DNA damage.

Having to do with the nose and pharynx.

An aberrant new growth of abnormal cells or tissues; tumor.

Nonmalignant tumors that secrete epinephrine and norepinephrines.

Inflammation of the pleura, the linings of the lungs and chest cavity.

Any lung disease caused by dust inhalation.

Fluid in the lungs.

Having to do with the kidneys.

Inflammation of the nasal mucous membrane. 
Teratogen:

Tachynpnea :

\section{Chemical Terms}

Flash point (FP):

Homologue:

Vapor pressure:

Risk Assessment Terms

Frank effect level (FEL):

Lethal concentration(50) (LC50):

Letha] dose(50) (LDDD50):

Lowest observed adverse effect level (LOAEL):

Lowest effect level (LEL):
A substance that causes fetal abnormalities, skeletal and visceral malformations, and functional/behavioral deviations.

Abnormally fast breathing.

The lowest temperature at which vapors of a combustible substance ignite in air when exposed to flame; an indication of the fire and explosion hazard posed by a chemical.

One of a series of organic compounds that differ from each other by a $\mathrm{CH}_{2}$, such as the methane series $\mathrm{C}_{n} \mathrm{H}_{2 n+2}$, in which there is a similarity between the compounds in the series and a graded change of their properties.

A measure of a chemical's volatility, expressed in millimeters of mercury $(\mathrm{mm} \mathrm{Hg})$.

The level of exposure which produces a statistically or biologically significant increase in frequency or severity of unmistakable adverse effects, such as irreversible functional impairment or mortality, in an exposed population when compared to its appropriate control.

A calculated concentration of a chemical in air to which exposure for a specific length of time is expected to cause death in $50 \%$ of a defined experimental animal population.

The dose of a chemical that has been calculated to cause death in $50 \%$ of a defined animal population.

The lowest exposure level at which there are statistically or biologically significant increases in frequency or severity of adverse effects between the exposed population and its appropriate control group.

Same as LOAEL. 
No observed adverse effect level (NOAEL):

No observed effect level (NOEL):

Slope factor:

Short-term exposure 1 imit (STEL):

Threshold Limit Value ( $T L V)$ :

Toxicity Value:

Weight-of-Evidence Classification:

Working Level (WL):
An exposure level at which there are no statistically or biologically significant increases in the frequency or severity of adverse effects between the exposed population and its appropriate control; some effects may be produced at this level, but they are not considered as adverse or precursors to adverse effects. In an experiment with several NOAELs, the regulatory focus is primarily on the highest one, leading to the common usage of the term NOAEL as the highest exposure without adverse effect.

An exposure level at which there are no statistically or biologically significant increases in the frequency or severity of any effect between the exposed population and its appropriate control.

A plausible upper bound estimate of the probability of a response per unit intake of a chemical over a lifetime.

An OSHA limit for the maximum concentration of a toxic that a worker should be exposed to during a specified period of time, usually 15 minutes.

Recommended guidelines for occupational exposure to airborne contaminants published by the American Conference of Governmental Industrial Hygienists (ACGIH). The value is specified as a time-weighted average (TWA) representing the average concentration (in $\mathrm{mg} /$ cubic-meter) for an 8-hour workday and a 40-hour work week to which nearly all workers may be repeatedly exposed, day after day, without adverse effect.

A numerical expression of a substance's dose-response relationship that is used in risk assessments. The most conmon toxicity values used in EPA risk assessments are reference doses (RfDs) for noncarcinogenic effects and slope factors for carcinogenic effects.

An EPA classification system for characterizing the extent to which the available data indicate that an agent is a human carcinogen.

A unit of measure of the exposure rate to radon and $i$ ts progeny defined as the quantity of short-lived progeny that will result in $1.3 \times 10^{5} \mathrm{MeV}$ of potential alpha energy per liter of air. Exposures are measured in working level months (WLM). 
PNL -7505 Vol. 1

UC -350

\section{DISTRIBUTION}

No. of

Copies

OFFSITE

2 DOE/Office of Scientific and Technical Information

25 G. C. Insley Bonneville Power Administration P.0. Box 3621 Portland, Oregon 97208-3621

\section{ONSITE}

DOE Richland Operations office

R. B. Goranson
No. of

Copies

14 Pacific Northwest Laboratory

M. C. Baechler (5)

M. R. Brambley

L. D. Kannberg

R. D. Stenner

Publishing Coordination

Technical Report Files (5) 
